Published in "Archaeometry 49 (1): 23-52, 2007"

which should be cited to refer to this work.

\title{
CLAY RESOURCES AND TECHNICAL CHOICES FOR NEOLITHIC POTTERY (CHALAIN, JURA, FRANCE): CHEMICAL, MINERALOGICAL AND GRAIN-SIZE ANALYSES*
}

\author{
R. MARTINEAU§ \\ Laboratory of Archaeology, Cultures and Societies, UMR 5594, CNRS/University of Burgundy, Earth Sciences \\ Centre, 6 bd Gabriel, 21000 Dijon, France and Department of Geosciences, University of Fribourg, \\ Switzerland
}

\section{A.-V. WALTER-SIMONNET}

Laboratory of Chrono-écologie, UMR 6565, CNRS/University of Franche-Comté, 16 route de Gray, 25030 Besançon cedex, France

\section{B. GROBÉTY}

Department of Geosciences, Petrography and Mineralogy, University of Fribourg, chemin du musée 6, 1700 Fribourg, Switzerland

and M. BUATIER

Laboratory of Geosciences, University of Franche-Comté, 16 route de Gray, 25030 Besançon cedex, France

Many authors have considered pottery manufacturing constraints and sociocultural elements as factors in change in past civilizations over time. The main issue of this research is to better understand the reasons for changes, or choices, in pottery raw materials. The very precise and detailed stratigraphy and cultural succession of occupations is based on dendrochronological data from the lake-dwelling sites of Chalain (Jura, France). Petrographic, palaeontological and chemical analyses were used to determine the nature and origins of the raw materials used by the Neolithic potters. Stratigraphy and dendrochronological data were used to reconstruct in detail the evolution dynamics of fabric changes. Several raw material sources were identified for many of the pottery groups. Each of them was sampled for qualitative experimental tests of pottery forming. The experimental results show a high variability between the sediments tested. This variability was quantitatively estimated by XRF, XRD, the Rietveld method, calcium carbonate quantification and laser grain-size analyses of matrices, indirect measures of plasticity. These analytical results allow a better understanding of the differences observed in the experimental tests. On the basis of these experimental and analytical results, changing parameters such as pottery manufacturing constraints, mineralogical characteristics of raw materials and sociocultural factors are considered. In conclusion, all the social and technical parameters, in each archaeological context, must be taken into account for a better understanding of the changes occurring throughout the chronological sequence.

KEYWORDS: NEOLITHIC, CERAMIC TECHNOLOGY, JURA, HORGEN, CLAIRVAUX CULTURE, LAKE OF CHALAIN, PETROGRAPHY, CLAY, LASER GRAIN-SIZE ANALYSIS, X-RAY DIFFRACTION, RIETVELD METHOD, TECHNICAL CHOICES 


\section{INTRODUCTION}

Chemical and mineralogical investigations of Neolithic pottery clearly reveal that the wide variety of raw materials used is related to the natural diversity of the environment. The idea behind this paper stems from the observation that some of the raw materials used by the Neolithic potters would be deemed of poor quality by potters today. Moreover, sudden changes from one raw material source to another were common. Such changes have been observed in various archaeological sites belonging to different Neolithic or protohistoric contexts (Balfet 1962; Courtois 1971; Hultén 1977; Steponaitis 1984; Constantin 1985; Constantin and Courtois 1985; Allen 1991; Echallier and Courtin 1994; Molinas 1995; Morzadec 1996; Colas 2000; Martineau 2000a,b; Sénépart and Convertini 2000). Within the framework of a general study of raw materials and techniques of Late Neolithic pottery from lake dwellings in Chalain and Clairvaux (Jura, France) (Martineau 2000a), the origin of several raw materials has been identified (Martineau et al. 2000 and in press). From a modern ceramic manufacturing point of view, some of the clays processed by the Neolithic potters are of poor quality; that is, with low plasticity and a high carbonate content.

The transition period from one culture to the next is not only accompanied by changes in pottery style, but also in the raw material source exploited by potters. Several observations contradict the well-accepted notions that ancient potters predominantly used the nearest outcrops as their raw material source, and that Neolithic people habitually settled where clay and other resources were readily accessible. Ethnographic evidence has clearly established that clay and temper are mainly exploited within a radius of $7 \mathrm{~km}(86 \%$ for clay and $91 \%$ for temper; Arnold $1985,2005)$. But these results do not signify that raw material sources are always located at the archaeological (or ethnographic) site. Only in $37 \%$ and $49 \%$ of cases, for clay and temper, respectively, are sources found at less than $1 \mathrm{~km}$ from the production site (Arnold 1985, 2005).

In the region studied, the nearest clay outcrops (located under the dwelling sites) seem to have been mainly exploited for manufacturing the floor structure beneath the fireplaces in houses, but generally not for pottery manufacture. Similar dichotomous situations have been observed at Swiss Neolithic sites (Di Pierro 2002, 2003; Bonzon 2003). Ceramic artefacts can be divided into two categories: the first is pottery, while the second is composed of fireplace floor structures and building materials (such as cobs and loom-weights). Each category corresponds to one specific type of raw material.

Fundamental questions arise concerning the interrelations between raw material constraints and their selection, which may depend on natural diversity and accessibility. One of the main aims of this paper is to suggest reasons for the sudden change in the choice of materials, which forced potters to introduce the transport of raw materials as a new step in the "chaîne opératoire'. Behind this question stands the theoretical debate on ceramic ecology (Matson 1965; Kolb 1989) and cultural identity (Constantin and Courtois 1985; Gosselain 1995; Gosselain and Livingstone Smith 1995). This is one facet of the eternal debate on culture and nature. But this paper relies rather on an ethnological theory of material culture, which considers that technical aspects, such as the choice of raw materials, are an integral part of any culture (Lemonnier 1986, 1993; Latour and Lemonnier 1994).

What was the relationship of the Neolithic potters to their environment? Did they exploit environmental resources based on technical choices or not? What were the main factors responsible for technical changes and choices? Recently, these issues have given rise to substantial debate (Sillar and Tite 2000; Cumberpatch et al. 2001; Sillar et al. 2001). Some studies concentrate on the cultural peculiarities of ceramic techniques, while others focus on the properties and functionality of the final products as a driving force for the choice of some 
raw materials. However, the influence of the quality of raw materials on the manufacturing process is an aspect that is rarely considered. The analyses presented here indicate that the arrival of a new population with new techniques, habits, know-how or environmental knowledge, in a new territory, could be one of the main arguments that may have led the Neolithic potters of Chalain and Clairvaux to change the raw material sources.

Sillar and Tite (2000), Cumberpatch et al. (2001) and Sillar et al. (2001) have criticized the systematic opposition of technical and social aspects in archaeological contexts. The choice of a technology responds to cultural, functional and production objectives, at one and the same time. Therefore, material science aspects (experimental, chemical and physical data) have to be considered and also included in archaeological or ethno-archaeological studies. The morphological and decorative variations in pottery styles are thought to respond to fashion changes. Techniques respond to different mechanisms, related to apprenticeships of technical knowledge and know-how. The point of view of the techno-functionalists is very different. Today, in our consumer society, maximum yield and performance are the main objectives. It is difficult to imagine that these objectives existed as such in the past, particularly during the Neolithic period. Nevertheless, there are constraints in the use of any raw material, related to its physical and mechanical properties. The choice of raw materials also imposes constraints on the different stages in the pottery 'chaîne opératoire'.

\section{THE ARCHAEOLOGICAL CONTEXT}

\section{Ceramic types and dating}

This study covers a chronological sequence from c. 3169 BC to 2980 BC (calendar years; Lavier 1996) and includes 604 pots of Chalain 2 (layers C and A//), Chalain 3 (layers VIII, VI and IV) and Chalain 4 (phases 1-4).

Two main types of pottery are compared in this study. The first type belongs to the Horgen culture (c. 3169-3080 BC) and is characterized by flat-based pots (Table 1). Some of these ceramics were produced using marly Dryas limestones found in the vicinity of the lake dwellings. Horgen pottery was formed by joining internal rings, and quickly smoothing the outer and inner surfaces (Martineau 2000a; see also Table 1). The second type belongs to the Early Clairvaux culture (c. 3025-2980 BC) and is characterized by pottery with rounded bases. This pottery was produced by alternating internal and external rings (Table 1), which were joined using a bone tool (Martineau 2002; Martineau and Maigrot 2004). These technical and morphological changes from one culture to the other reflect a more general change that affected all aspects of material culture at that moment (Pétrequin 1997a).

Both types of pottery were fired in open fires (Martineau and Pétrequin 2000). The large carbonate inclusions of the raw materials required thick walls and quick firing to prevent cracking. Pétrequin et al. (1994) indicate that pottery production was probably domestic. Organo-chemical analysis of residues found on the pottery walls demonstrated that all of them served for cooking purposes (Regert et al. 1999), indicating domestic usage.

\section{PETROGRAPHIC AND CHEMICAL CHARACTERIZATION OF CERAMIC FABRICS}

\section{Petrographic and palaeontological characterizations}

For the period studied, 604 pottery samples have been petrographically and paleontologically analysed. 
Table 1 The archaeological context; the morphological, technical and raw material data of the pottery of the Early Clairvaux and Horgen cultures

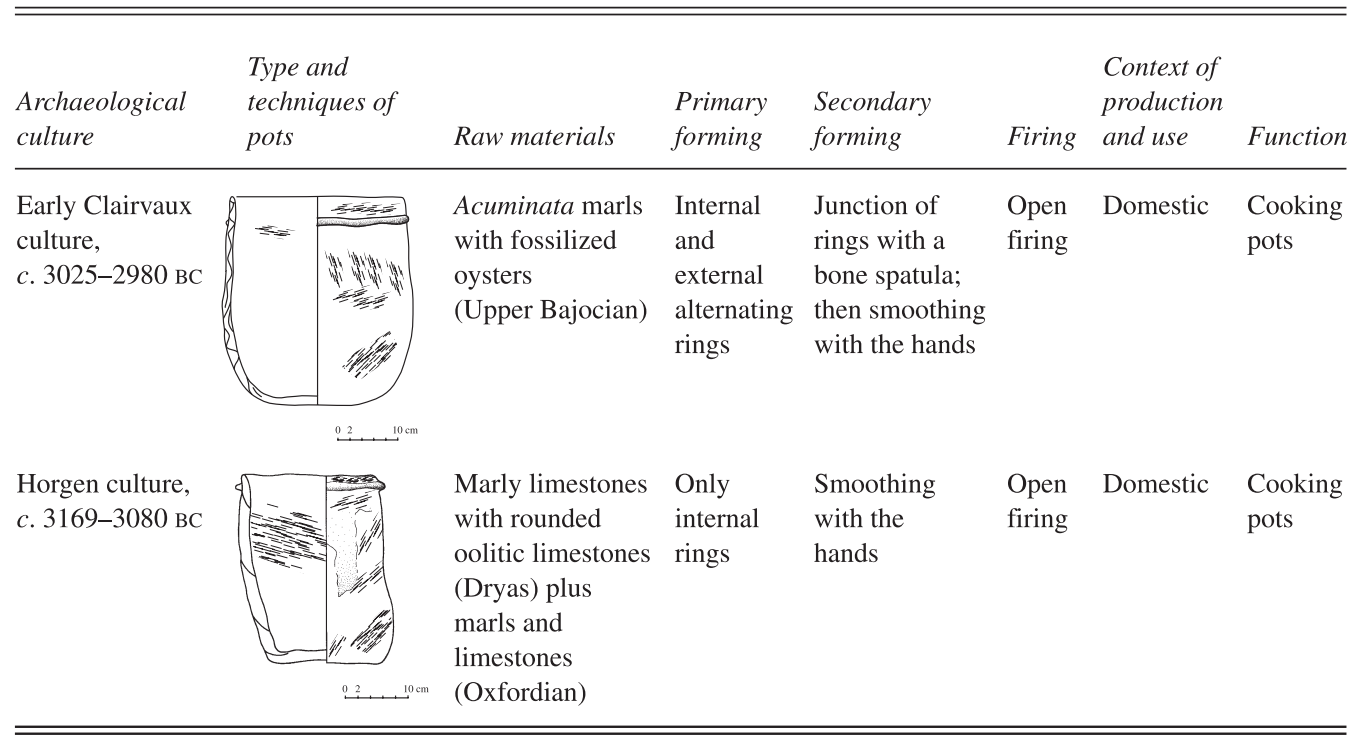

The Acuminata group (groups 11 and 12)

The pottery in this group contains a large quantity of natural fossil inclusions (Martineau et al. 2000). Most of them are oysters (Praeexogyra acuminata), which are attributable to the Upper Bajocian period (J1b) (Contini 1970; Dumanois 1982) and are associated with bryozoans, crinoids and urchin spines (Fig. 1). This fossil assemblage is characteristic of the Acuminata marls (Contini 1970), corresponding to the Plasne and Châtillon marls of Girardot (1890-6). Identification leaves no doubt about the origin of the raw materials (Martineau et al. 2000). In these marls, Acuminata shells are naturally included in the argillaceous matrix. They were not added to the clay by the potters. Acuminata marls are sediments that form a natural ready-touse pottery paste.

The rounded oolitic limestone group (group 19)

The pottery from this group is characterized by inclusions of rounded oolitic limestone fragments, rounded quartz and some mica crystals (Fig. 1). Occasionally, pieces of micritic limestone, crinoids and some shell fragments occur. Macroscopically, the matrix consists of white, fine-grained carbonates. The rounded shape of the inclusions suggests that they are of natural origin. This sediment, like the Acuminata marls, is also a natural paste.

\section{Chemical characterization of fabrics}

Chemical characterization was carried out on 20 samples, principally to define the variability of the ceramic composition, and to compare it with the natural sediment composition (12 samples). The $\mathrm{CaO}$ composition depends largely on the quantity of carbonate and fossil inclusions in the ceramics. Two chemical groups of ceramic fabrics are distinguishable on the basis of $\mathrm{CaO}$, 


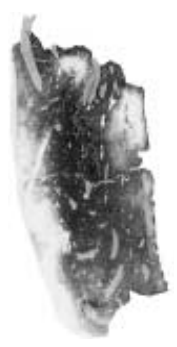

Acuminata

Archaeology

2425

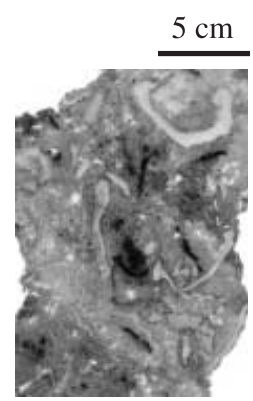

Acuminata

Sediment 70

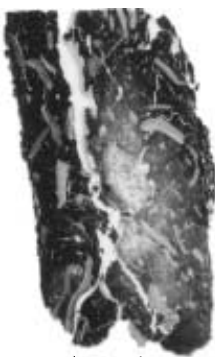

Acuminata

Archaeology

4182

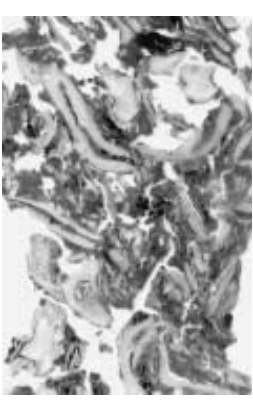

Acuminata

Sediment 79

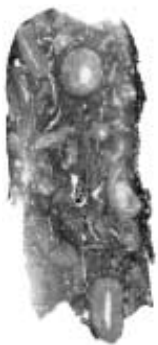

Acuminata

Archaeology

2390

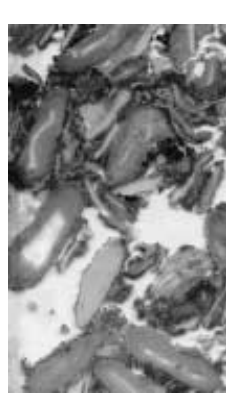

Acuminata

Sediment 76

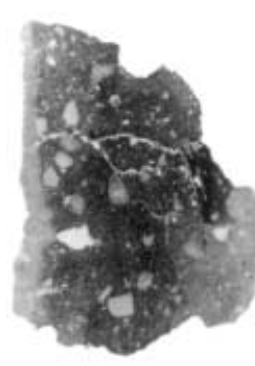

Dryas

Archaeology

3077

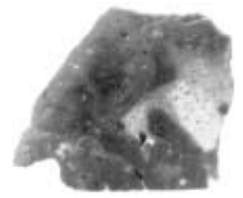

Dryas

Archaeology 3080

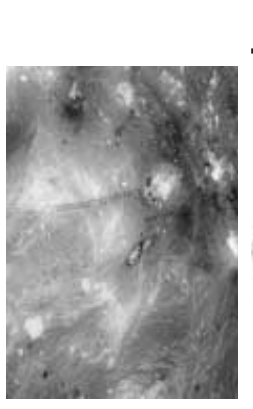

Dryas

Sediment 36
$5 \mathrm{~cm}$

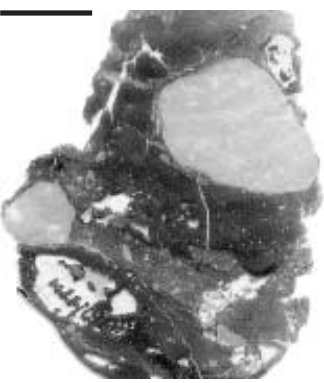

Dryas

Sediment 36

Figure 1 On the left, thin sections of Acuminata marls (M2): the main inclusions are natural fossil oysters from the Upper Bajocian (magnification $\times 2$ ). Samples 70 and 76 are the most similar to the archaeological pottery. On the right, thin sections of Dryas sediment from the western shore of the lake of Chalain (D6): the rare inclusions are detrital rounded oolitic limestone, micritic limestones and quartz (magnification $\times 2)$. The two natural sediments show the high variability in the Dryas outcrops, as do the archaeological samples. Archaeological numbers refer to Appendix A and sediment numbers to Table 2.

$\mathrm{SiO}_{2}, \mathrm{~K}_{2} \mathrm{O}, \mathrm{Al}_{2} \mathrm{O}_{3}, \mathrm{Fe}_{2} \mathrm{O}_{3}, \mathrm{Ni}, \mathrm{Cr}$ and $\mathrm{Ba}$ (Figs 2 and 3; Appendix A). The ternary diagram cumulates between $84.9 \%$ and $97.5 \%$ of the elements. One group (group A) concerns all pots with Acuminata inclusions (groups 11 and 12). The range of $\mathrm{CaO}$ in group $\mathrm{A}$ is between $15.7 \%$ and $46.6 \%$. The second chemical group, group B, corresponds to ceramics with white matrix and rounded oolitic limestone and quartz (group 19; Fig. 2). The range of $\mathrm{CaO}$ in group $\mathrm{B}$ is between $51.7 \%$ and $70.5 \%$. The two groups are very rich in $\mathrm{CaO}$, but $\mathrm{CaO}$ is higher in group $\mathrm{B}$ than in the Acuminata group. In addition, $\mathrm{SiO}_{2}, \mathrm{Al}_{2} \mathrm{O}_{3}, \mathrm{~K}_{2} \mathrm{O}$ and $\mathrm{Fe}_{2} \mathrm{O}_{3}$ are lower in group $\mathrm{B}$ than in group A (Figs 2 and 3; Appendix A). However, the chemical composition in the triangular diagram (Fig. 2) clearly shows two groups corresponding to petrographic groups 11 and 12 (Acuminata fabric) and chemical group A, on the one hand, and to petrographic group 19 (rounded quartz and Dryas limestones) and chemical group B, on the other. These results confirm the petrographic and palaeontological characterizations and distinctions between Acuminata marls and rounded oolitic limestone sediments. The most important result here is that the chemical composition of some of the natural sediments corresponds to that of the archaeological pottery, as we shall see below in detail. 


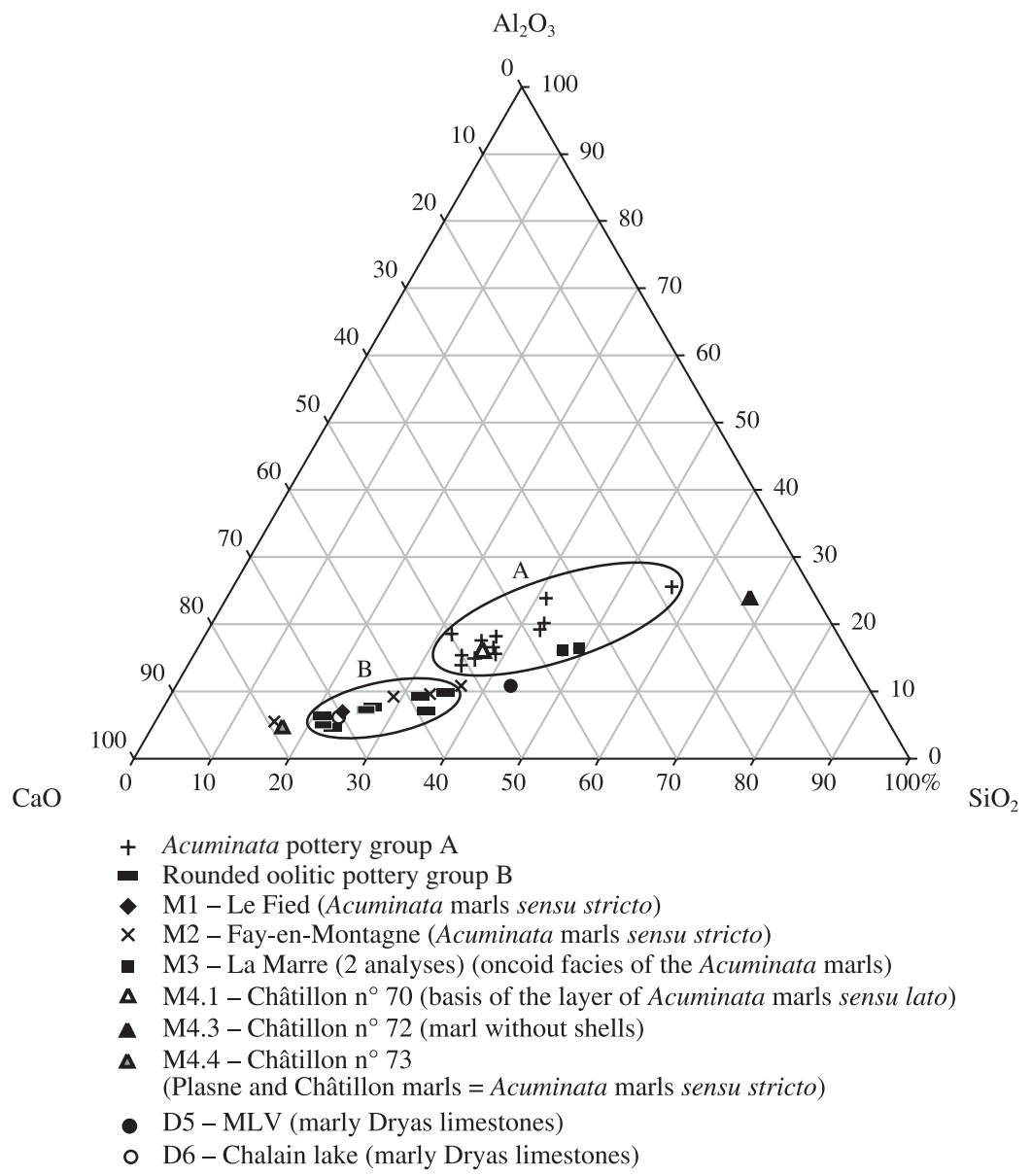

Figure 2 A ternary diagram comprising $\mathrm{CaO} \%$, $\mathrm{SiO}_{2} \%$ and $\mathrm{Al}_{2} \mathrm{O}_{3} \%$, showing two pottery groups and their relations with the natural sediment compositions. A, Acuminata marls; $B$, rounded oolitic pottery group. The natural sample best correlated with pottery group A is M4.1. The natural sample best correlated with pottery group B is D6.

\section{THE GEOLOGICAL CONTEXT}

The lake of Chalain (Jura, France) is located in the Combe d'Ain, on the eastern side of the French Jura. The geological environment of the lake dwellings of Chalain is dominated by carbonate-rich rocks of Jurassic age (Guillaume and Guillaume 1965; and see Fig. 4). In the Combe d'Ain, the bedrock is covered by quaternary clay sediments deposited during Würmian glaciation and several cold phases during the Late Glacial period (Campy 1982). Due to their high carbonate, low clay content, the rocks and soils of the Combe d'Ain area are 'poor pottery raw materials'.

Previous studies and raw material analyses have allowed the geological provenance of several raw materials to be identified (Martineau et al. 2000 and in press). The raw materials used by the Neolithic potters from the lake of Chalain are summarized on the map shown in Figure 4. The identification of four geological formations used by the Neolithic potters allows comparison 


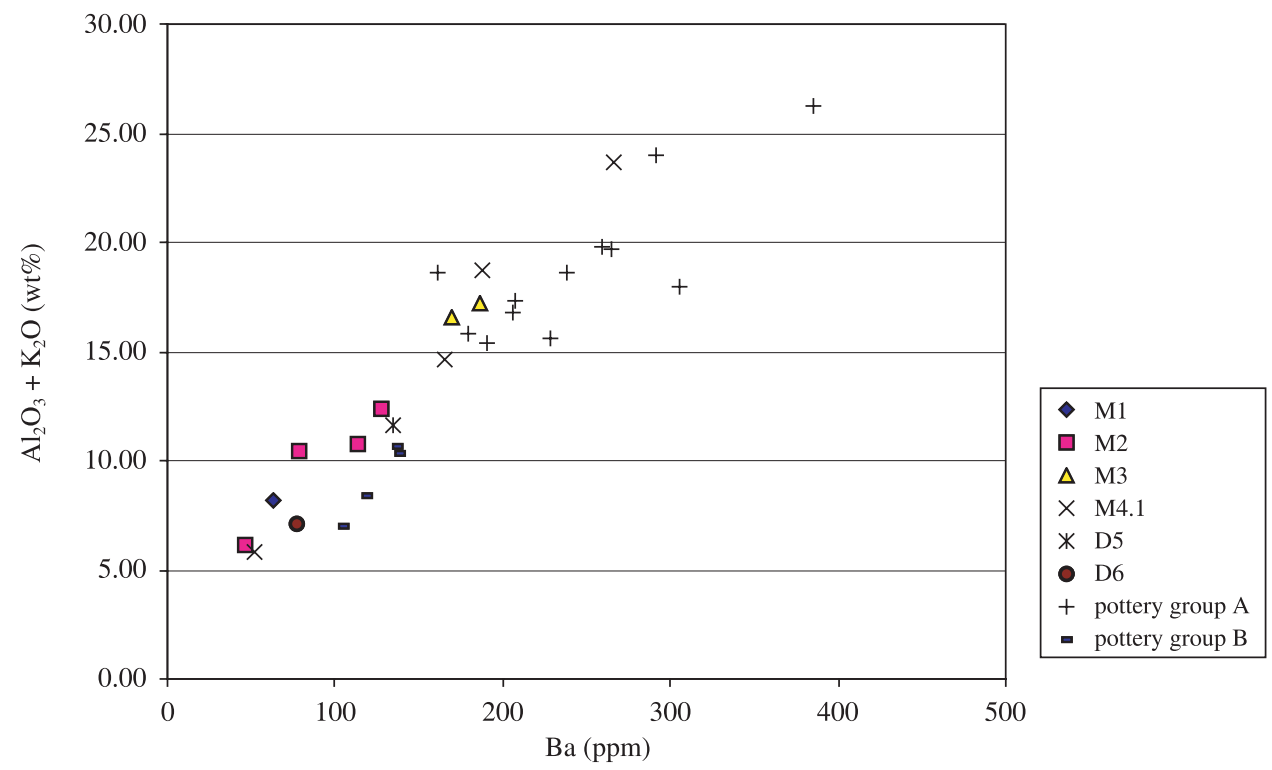

Figure 3 The distribution of $\mathrm{Al}_{2} \mathrm{O}_{3}+\mathrm{K}_{2} \mathrm{O} / \mathrm{Ba}$ clearly confirms the two chemical groups corresponding to the petrographic groups $A$ and $B$.

with the general geological context that has previously been presented (Fig. 4). In the area studied, only a small part of the available raw materials has been exploited by the potters' community (Fig. 4). We do not know the reasons for these 'choices'. We do not know whether it is even possible to speak of 'choice'. We shall focus our attention on two main raw materials: the Acuminata marls and the marly Dryas limestones.

\section{Clayey sediment evidence}

The Acuminata marls from the Upper Bajocian The outcrops of Acuminata marls are rare and difficult to localize. They are located on the Lons-le-Saunier plateau, at 5-12 km from the lake dwellings (Fig. 4). Extensive prospecting revealed only four accessible outcrops. The more detailed stratigraphic section of Châtillon 'La Percée' shows three distinct layers (Girardot 1890-6, Contini 1970), summarized in the stratigraphic chart shown in Figure 5. At the basic level are the Lower Jurassic marly limestones of Courbouzon (Girardot 1890-6) with rare Acuminata shells and brachiopods (Parkinsonia subarietis Wetzel and Terebratula cf. masticonensis Liss), corresponding to the base of Acuminata marls s.l. of Contini (1970) (Fig. 5). The second layer is composed of Acuminata marls (the Plasne and Châtillon marls of Girardot 1890-6), referred to as 'Acuminata marls s.s.' by Contini (1970). In this layer we have distinguished a base level of marl without shells and an upper level of marl with many Acuminata shells. Plasne oolitic alternated marls and limestones form the third upper layer (Fig. 5). In this level, the shells are coated in oncoids and associated with Parkinsonia parkinsoni Sow (Contini 1970). This type of level is called 'oncoid facies of the Acuminata marls' (the Plasne pisolitic marls of Girardot 1890-6). These three facies of Girardot have been regrouped by Contini (1970) in the same formation: the marls of Plasne. The systematic presence of abundant Acuminata shells in this formation has led to the name 'Acuminata marls'. 


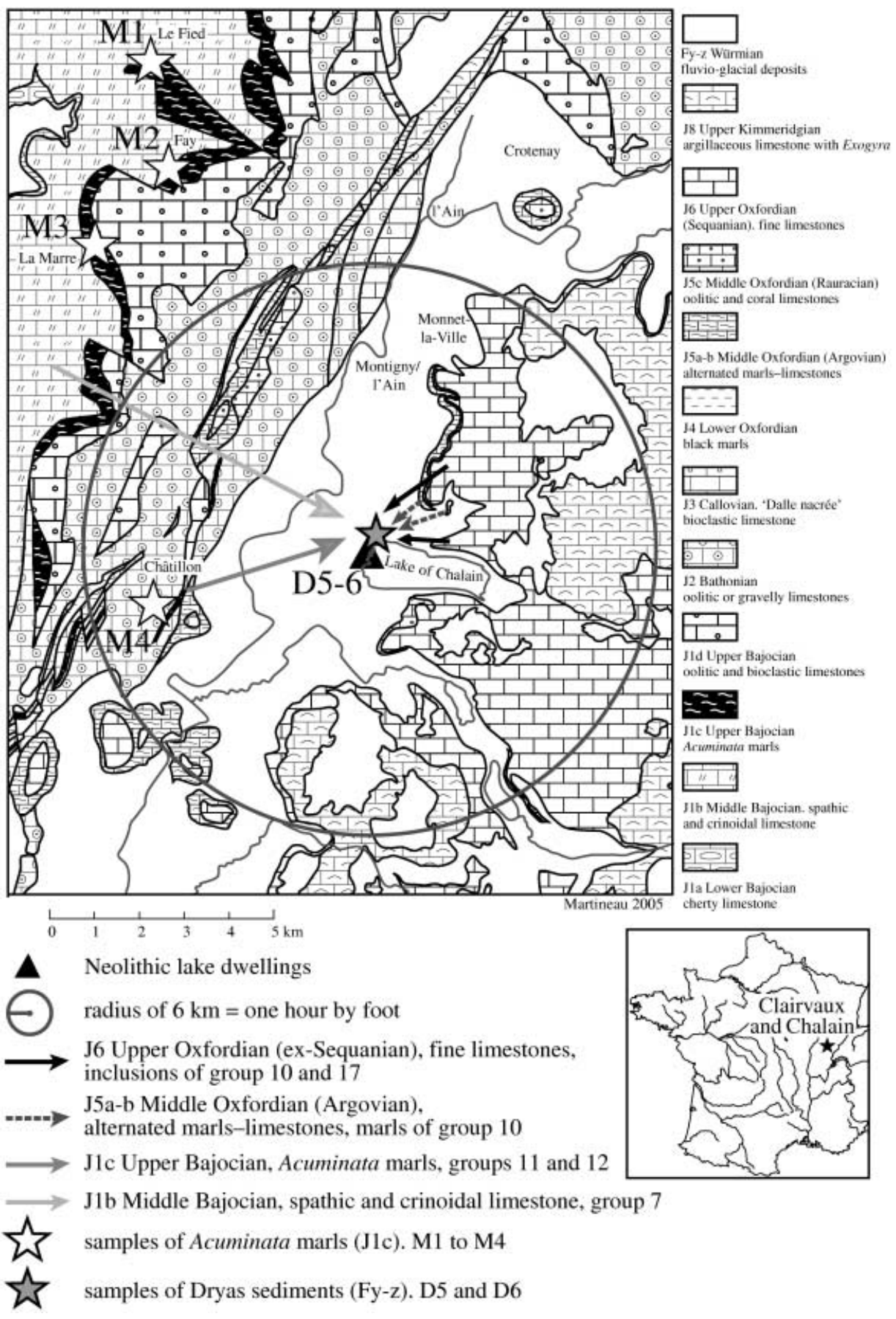

Figure 4 The geological context of the Neolithic sites of the lake of Chalain. In this area, all the sediments are carbonate rich. The map shows the locations of the sediments used by the Neolithic potters between c. 3169 BC and 2950 BC. The Dryas sediments are located at the Neolithic sites. The Oxfordian marls are located $1.5 \mathrm{~km}$ from the lake-dwelling sites. The Acuminata marls are situated 5-12 km from the lake-dwelling sites. 


\section{BATHONIAN}

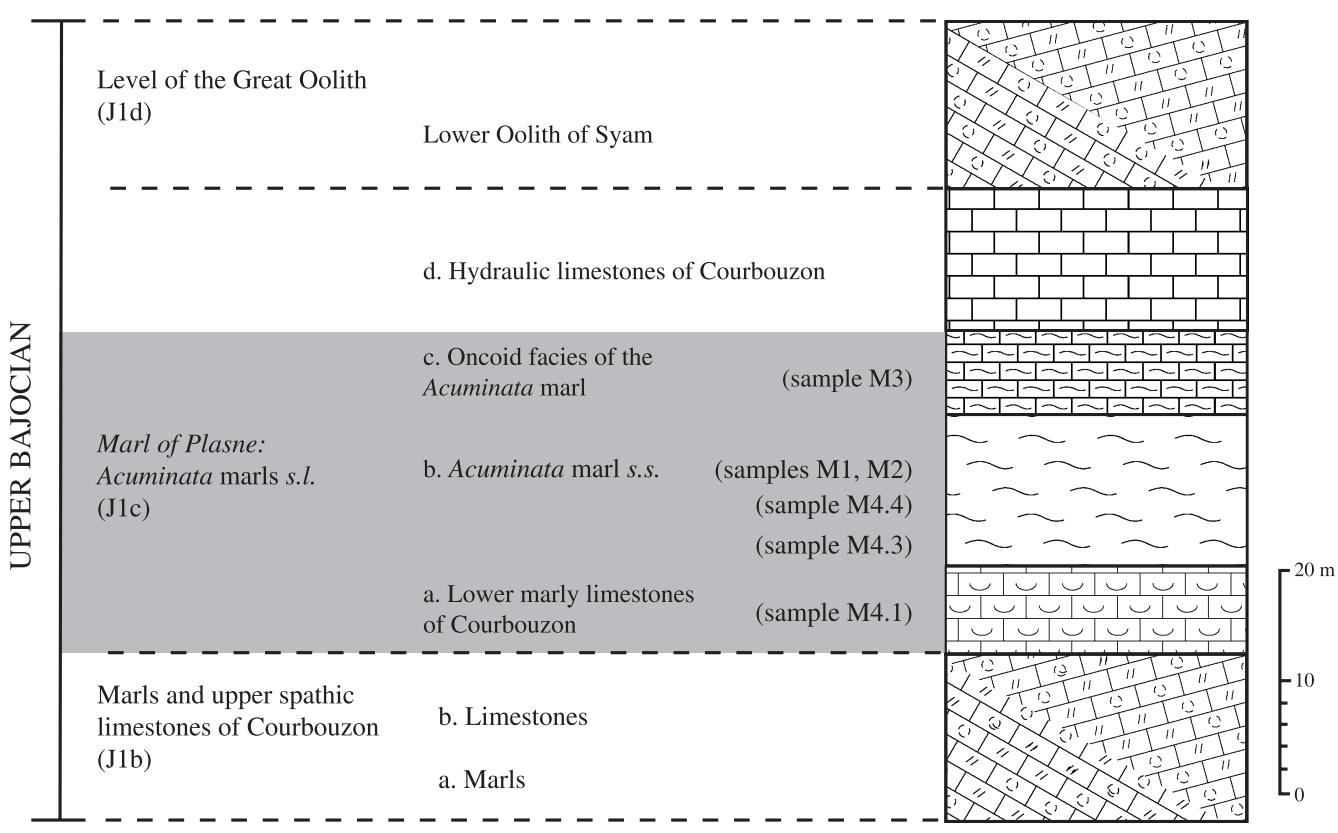

MIDDLE BAJOCIAN

Figure 5 A stratigraphic log of the Upper Bajocian in the Lons-le-Saunier area (Contini 1970). The analysed samples have been placed in the corresponding levels.

Samples M1 and M2 were taken from the Acuminata marls sensu stricto, whereas sample M3 represents the oncoid facies of the Acuminata marls s.l. (Table 2; Figs 4 and 5). M4.1 is a sample of the Lower Jurassic marly Courbouzon limestones of Girardot (Acuminata marls sensu lato). Sample M4.4 corresponds to Plasne marls (Acuminata marls s.s. of Contini 1970). M4.3 comes from a little clayey level without fossils, in Acuminata marls s.s., located between M4.1 and M4.4. This type of level corresponds to lateral facies variations, frequently found in these formations, and related to variability in sedimentation. On the geological map, no distinction has been made between the Acuminata marls sensu stricto, and the oncoid facies of Acuminata marls (Chauve et al. 1993).

All of these sediments are very rich in CaO (Contini 1970, Dumanois 1982), but some variability exists. Such variations will be very useful for further comparison between archaeological pottery and these natural sediments.

The marly Dryas limestones Two samples (D5 and D6) of marly Dryas limestones from outcrops on the western shore of the lake of Chalain (Fig. 4 and Table 2) were analysed. The inclusions of D5 and D6 are characteristic of a detrital terrigenous allochthonous sediment (noted as 'Fy-z' on the geological map) deposited during the cold phases of the Late Glacial (Old and Younger Dryas), between 15000 and 10000 BP (Magny 1991, 1992; Bossuet et al. 1996, 1997). These sediments are often covered by lacustrine chalk, which constitutes the substratum of the lake (Campy 1982), but several outcrops of the underlying Dryas sediments are accessible on the western shore of the lake of Chalain (Fig. 4). 
Table 2 Natural sediment references studied by chemical, mineralogical and grain-size analyses

\begin{tabular}{|c|c|c|c|c|}
\hline Sample & Location & Geological attribution & $\begin{array}{l}\text { Number of } \\
\text { thin section }\end{array}$ & Lambert co-ordinates \\
\hline M1 & Le Fied & $\begin{array}{l}\text { Acuminata marl s.s. } \\
\text { Upper Bajocian }(\mathrm{J} 1 \mathrm{c})\end{array}$ & 52 & $x=858.4, y=184.5$ \\
\hline M2 & Fay-en-Montagne & $\begin{array}{l}\text { Acuminata marl s.s. } \\
\text { Upper Bajocian }(\mathrm{J} 1 \mathrm{c})\end{array}$ & 79 & $x=859.8, y=182.5$ \\
\hline M3 & La Marre & $\begin{array}{l}\text { Oncoid facies of Acuminata } \\
\text { marl s.l. Upper Bajocian (J1c) }\end{array}$ & 77 & $x=857.5, y=181$ \\
\hline M4.1 & Chatillon 'La Percée' & $\begin{array}{l}\text { Acuminata marl s.1. } \\
\text { Upper Bajocian }(\mathrm{J} 1 \mathrm{c})\end{array}$ & 70 & $x=859, y=188$ \\
\hline M4.3 & Chatillon 'La Percée' & $\begin{array}{l}\text { Acuminata marl s.s. Upper } \\
\text { Bajocian (J1c) }\end{array}$ & 72 & $x=859, y=189$ \\
\hline M4.4 & Chatillon 'La Percée' & $\begin{array}{l}\text { Acuminata marl s.s. Upper } \\
\text { Bajocian }(\mathrm{J} 1 \mathrm{c})\end{array}$ & 73 & $x=859, y=190$ \\
\hline D5 & Marigny-les-Vernois (MLV) & $\begin{array}{l}\text { Old and Younger Dryas, } \\
\text { Late glacial }(F y-z)\end{array}$ & 49 & $x=863.5, y=181.6$ \\
\hline D6 & $\begin{array}{l}\text { Station } 2 \text { of } \\
\text { lake of Chalain }\end{array}$ & $\begin{array}{l}\text { Old and Younger Dryas, } \\
\text { Late glacial (Fy-z) }\end{array}$ & 36 & $x=863, y=182$ \\
\hline
\end{tabular}

Mineralogically, D5 and D6 are identical, but the proportions of the quartz and carbonate natural inclusions are different, which may explain the chemical differences between them. In thin sections from D5, the quantity of quartz is higher than in sample D6, where quartz is rare. Moreover, quartz morphologies of the samples are different. In D5, the morphology of quartz is angular, whereas quartz is rounded in sample D6. After firing, the matrix of D5 is red, whereas the D6 matrix remains white, certainly because of its lower FeO content (Appendix A).

These Dryas sediments are very rich in $\mathrm{CaO}$, whereas the $\mathrm{CaO}$ content of D6 $(66.06 \%)$ is higher than the $\mathrm{CaO}$ content $(42.18 \%)$ of D5 (Fig. 2, Appendix A). In the same way, $\mathrm{Al}_{2} \mathrm{O}_{3}$ and $\mathrm{SiO}_{2}$ are almost twice as high in D5 (9.85\% and 39.45\%, respectively) as in D6 (5.91\% and 21.69\%, respectively) (Fig. 2, Appendix A). Samples D5 and D6 can be identified and distinguished by their chemical and petrographic composition.

\section{COMPARISONS BETWEEN POTTERY AND SEDIMENTS}

The chemical discussion is based on a ternary diagram depicting $\mathrm{Al}_{2} \mathrm{O}_{3}, \mathrm{SiO}_{2}$ and $\mathrm{CaO}$, regrouping between $84.89 \%$ and $97.53 \%$ of the bulk chemical composition of the samples.

The marly Dryas limestones in sample D5 have a higher amount of quartz inclusions than pottery group $\mathrm{B}$. The chemical composition of $\mathrm{D} 5$ is higher in $\mathrm{SiO}_{2}$ and lower in $\mathrm{CaO}$ than pottery fabric group B (Fig. 2 and Appendix A). After firing, the colour of the D5 matrix is red, probably because of $\mathrm{FeO}$ discrepancies (Appendix A), whereas the group B pottery fabric matrix is white. However, textural analysis reveals a higher percentage of inclusions in D5 than in D6, which underlines the natural variability of these sediments. The percentage of quartz inclusions in D6 corresponds well with that found in pottery group B. The chemical 
composition of D6 is similar to that of pottery group B. After firing, the D6 matrix remains white, as found in pottery group B. Thus, the archaeological thin sections for pottery group B show the same matrix colour and mineralogical inclusions as the marly Dryas limestones in sample D6 (Martineau 2000a). Analyses of all available sediment evidence confirm that sample D6 is far more compatible with pottery group B than sample D5 (Fig. 2).

Analyses show clearly that Acuminata marls have high carbonate variability. Sample M4.3 is an example of Acuminata marls without shells. It is low in $\mathrm{CaO}$, but rich in $\mathrm{SiO}_{2}$ and $\mathrm{Al}_{2} \mathrm{O}_{3}$, because of the clay concentration and the absence of shells (Fig. 2). Several samples of Acuminata marl sediments (M1, M2 and M4.4) have $\mathrm{CaO}$ contents higher than that of pottery group A. Their chemical composition corresponds to pottery group B but, as we have seen before, they are petrographically and palaeontologically incompatible with this fabric. On the contrary, sample M4.1 (the Lower Jurassic marly limestones of Courbouzon, corresponding to Acuminata marls sensu lato) from Châtillon coincides exactly with pottery group A (Fig. 2). The bulk chemical composition of this sample is compatible with that of pottery group A (Fig. 2, Appendix A). Sample M3, corresponding to the oncoid facies of Acuminata marls, is close to pottery group $\mathrm{A}$ in our diagram, but it differs in the amount of $\mathrm{SiO}_{2}$, which is slightly higher (Fig. 2, Appendix A). These two samples confirm chemically the observed petrographic and palaeontological compatibility of Acuminata marls with pottery group A, notably concerning samples M4.1 and, to a lesser extent, M3.

Textural comparisons of sediments and matrix (Figs 1 and 2) show a trend that confirms the chemical observations. The pottery in group A contains a lower quantity of fossil inclusions than some sediments. There is, however, great natural lateral variability in the sediment composition. The Châtillon M4.1 sample has the lowest percentage of fossil inclusions of the Acuminata samples, which explains its lower percentage in $\mathrm{CaO}$ (Fig. 2, Appendix A). In sample M4.1, the lower percentage of $\mathrm{CaO}$ shows a very good correlation with archaeological pottery group $\mathrm{A}$.

\section{THE ORIGINS OF THE POTTERY RAW MATERIALS}

It is surprising to note that sample M4 from Châtillon (Fig. 4) is the nearest Acuminata marl outcrop to the Chalain dwellings, $5 \mathrm{~km}$ from the lake of Chalain. Until about 30 years ago, this outcrop was far more visible in the landscape than today, because the exposed stratigraphic cross-section was $14 \mathrm{~m}$ high (Girardot 1890-6). Twentieth-century roadworks have raised the level of the road until only a $5 \mathrm{~m}$ difference remains (D. Contini pers.comm.).

It is interesting to observe that the situation is comparable for the marly Dryas limestones, the nearest clayey outcrop to the Chalain lake-dwelling sites (Fig. 4). For the two fabric groups $\mathrm{A}$ and $\mathrm{B}$, the inclusions are naturally mixed with the matrices. The Neolithic potters may have looked specifically for this type of sediment.

The bone tools used for the surface treatment of the green bodies found within the site of the lake dwellings are strong indications that the pottery was not manufactured close to the raw material source, but that the production sites were in the dwellings themselves. This required transport of heavy raw materials over a distance of at least $5 \mathrm{~km}$ to the Neolithic sites (Martineau and Maigrot 2004). This kind of transport would represent about an hour's journey each way.

\section{POTTERY FABRICS: ORIGINS AND TECHNOLOGICAL CHANGE}

The bar diagram of Figure 6 shows the different raw materials within the chronological sequence of the archaeological cultures studied. The more siliceous paste groups are placed on 


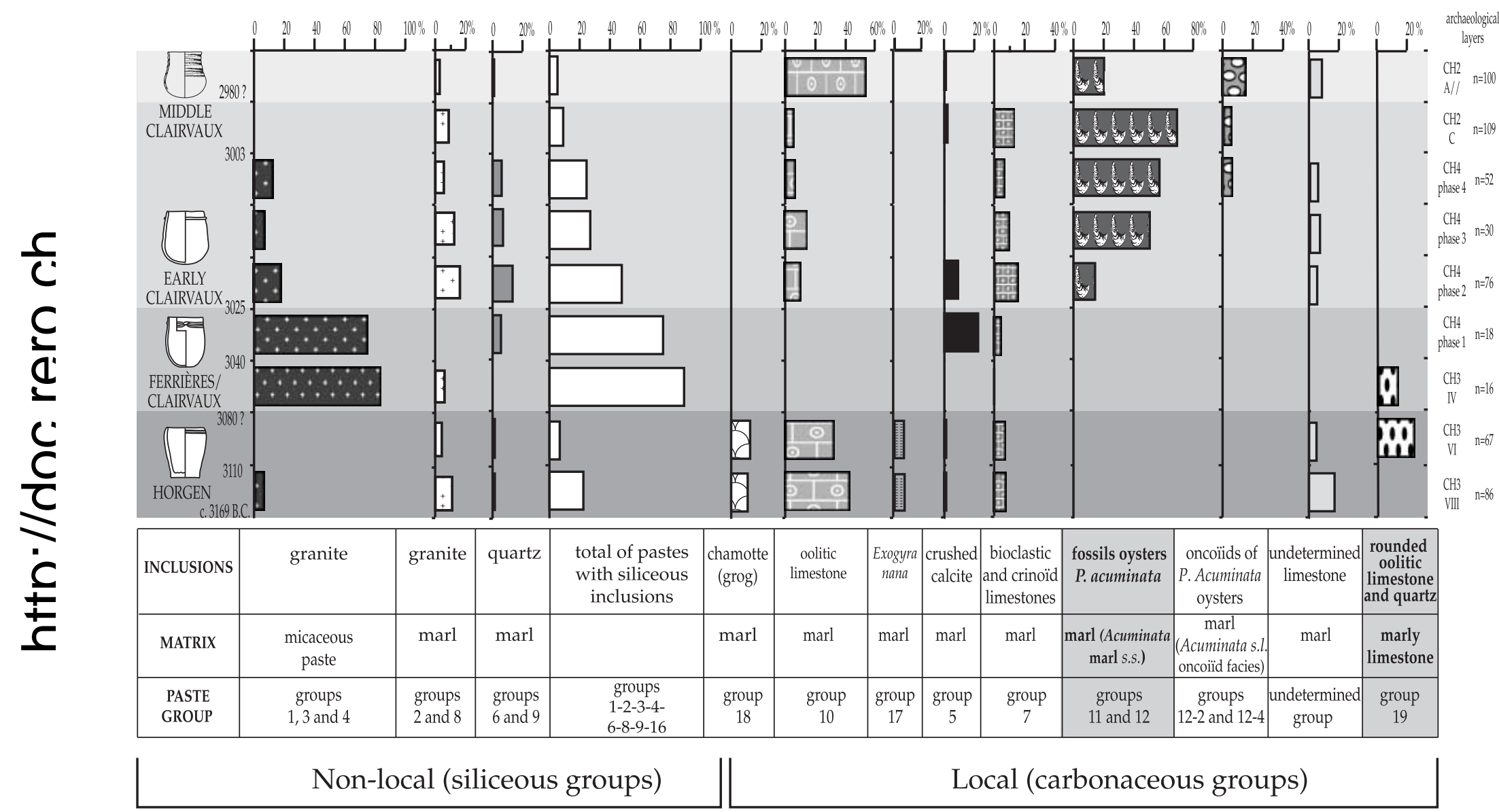

Figure 6 The chronological sequence and distribution of pottery paste groups. The carbonate proportion increases from left to right in the figure. Several raw materials changes have occurred during this two-century sequence. 
the left, whereas the more carbonate-rich ones are on the right of the figure. The pottery raw materials from Chalain can be subdivided into two categories and 12 main groups of pastes (Martineau 2000a,b; and see Fig. 6).

The first category is characterized by siliceous inclusions. The main group of this category is composed of granite rock fragments in a micaceous paste (Martineau et al. 2000; Di Pierro and Martineau 2002a,b). The second category is characterized by several types of carbonaterich (or very rich) matrices with a large variety of inclusions, such as limestone fragments or fossils (Fig. 6).

During the Horgen period, potters used several paste groups (groups 7, 10, 18 and 19)—notably group 10-with the highest frequency (Martineau 2000a). Crushed added oolitic limestone inclusions constitute the main type of inclusion in this pottery fabric. On the basis of angularity and sedimentological associations, we know that these inclusions were crushed and added to a marl. The inclusions from group 10 correspond to the 'Couches du Morillon' of the Upper Oxfordian (J6). The geological attribution of this fabric is attested by the presence of foraminifers, Lituolides Pseudocyclammina s.s. (formerly Alveosepta jaccardi from Sequanian), determined by A. Boullier (Geosciences Department, Besançon, France; see also Enay 1966; Guillaume 1964; Guillaume and Guillaume 1965; Gaillard 1983), in oolitic fragments (Martineau et al. in press). The nearest outcrop of this formation is located at 'sur la Côte', in Marigny/Ain (Jura), $1.5 \mathrm{~km}$ from the Neolithic lake-dwelling sites of Chalain (Fig. 4). The marls used for this paste group come from the Middle Oxfordian (J5a-b), and are located nearer than inclusions of the same group.

All of the carbonate groups have a local source (outcrops at a distance closer than $7 \mathrm{~km}$ ). However, while a potential source for the petrographic pottery groups 1, 3 and 4 (micaceous pastes with granite inclusions; Fig. 6) may be located $20 \mathrm{~km}$ away from the lake dwellings of Chalain, a more likely site is known to exist 50-60 km away (Campy 1982; Martineau 2000a; Martineau et al. 2000). These pottery groups, represented by 46 pots belonging to the Ferrières/ Clairvaux culture (c. 3045-3030 BC), were most probably not locally produced, but imported by an immigrant population, as proposed in the hypothesis of P. Pétrequin (Pétrequin 1993, 1997a,b, 1999; Pétrequin et al. 1998), or exchanged with another cultural group. After this period, pastes with siliceous inclusions were gradually replaced by carbonate pastes, notably the Acuminata marls s.l. (Fig. 6), which have already been characterized and localized.

In this paper, we focus on marls with fossilized oyster shells (Acuminata marls s.l.) and on marly Dryas limestones, with rare fragments of rounded oolitic limestone. The marly limestones of the Dryas sediments (group 19) were exploited in the Horgen culture, whereas the Acuminata marls were only used for pottery production during the Clairvaux culture (Table 1 and Fig. 6). Pottery made with marly Dryas limestone is only found in two layers of the chronological sequence. The respective percentages of pottery produced with this raw material are $26.9 \%$ from layer VI (18 pots) and $12.5 \%$ of pottery from layer IV (two pots) of Chalain 3 (Fig. 6).

The use of the Acuminata marls (groups 11 and 12) covers the period between c. 3025 BC and $2980 \mathrm{BC}$, corresponding to the Early Clairvaux culture. They were never employed during the Horgen culture or the Ferrières/Clairvaux culture (Chalain 3, layer IV), but became the main sediment exploited by the potters of Chalain during the Early Clairvaux culture (163 pots; Fig. 6). From $11 \%$ at the beginning, the proportion of Acuminata marls s.s. increased to $63.5 \%$ of the pastes used during this period (Fig. 6). From the end of the Early Clairvaux culture to the Middle Clairvaux culture, potters also used the oncoid facies of the Acuminata marls s.l. (between 5.5\% and 15\%) (Fig. 6). At the peak of the Acuminata marl s.l. exploitation, nearly $80 \%$ of the pottery from the Chalain sites was made using this raw material. 
Such a diversity of raw materials used in manufacture is a good archaeological context in which to seek possible simultaneous changes in sociocultural factors, and parameters for pottery raw materials, such as their physicochemical composition and mechanical properties.

\section{AN EXPERIMENTAL APPROACH TO SEDIMENT QUALITY}

\section{Questions about the nature of raw materials}

Acuminata marls and marly Dryas limestones are sediments that are very rich in $\mathrm{CaO}$. Moreover, Acuminata marls contain a large quantity of fossil inclusions. The marly Dryas limestones seem to have a very low plasticity. All of these observations highlight a surprising use of raw materials. This situation spurs us on to try to understand the reasons behind their use as pottery clays. Answers to this question require good knowledge and thorough analyses of these raw materials.

\section{Paste preparation and technical choice}

We performed a comparative experimental study between three kinds of paste preparation: exploitation of local sediments such as the Dryas sediments (natural mixing between clay and natural inclusions), utilization of local clay and the addition of local limestone inclusions, and utilization of Acuminata marl, found $5 \mathrm{~km}$ from the dwelling sites. The first method (Dryas sediments) requires only the extraction of the sediment, while for the second one (local clay and added inclusions) the limestone must be crushed, and then added to local clay and mixed in. The third method (the Acuminata marls) already involves a natural mixture of clay and inclusions, like the first one, but requires the transport of the sediment over $5 \mathrm{~km}$ to the dwelling sites. For the second type of paste preparation, we measured the time needed to crush limestone fragments to obtain a grain size from $2 \mathrm{~mm}$ to $7 \mathrm{~mm}$, like the fragments added to the Clairvaux pottery. About $1 \mathrm{~kg}$ of limestone can be crushed in $22 \mathrm{~min}$ (Martineau 1995; see also Table 3).

A comparative table shows the differences between these three modalities of paste preparation (Table 3). The Dryas sediments require no temper crushing and only a very short transport. The use of local clay requires local limestone to be crushed before it can be added. Acuminata marls with natural fossil inclusions require a lengthier transport of raw materials. The quantitative results show that the amount of time spent on the preparation of local clay with local limestone is higher than that spent on the acquisition of Acuminata marls, which is twice as high as for the Dryas sediments. Crushing and adding a local limestone to a local clay takes three times longer than using the Dryas sediments.

\section{Forming the body}

Our experimental approach to pottery techniques is based on approximately 10 years of training and practice, which represents the production of over three hundred pots (Martineau 1995, 2000a). Experimental pottery manufacturing used all six different sediment samples (Table 2). Pottery was produced with the same morphology and using the same techniques as in the past (Martineau 2000a, 2002; Martineau and Maigrot 2004: see also Table 1). From the potter's point of view, both the marly Dryas limestones and the Acuminata marl are 'poor pottery raw materials'. 


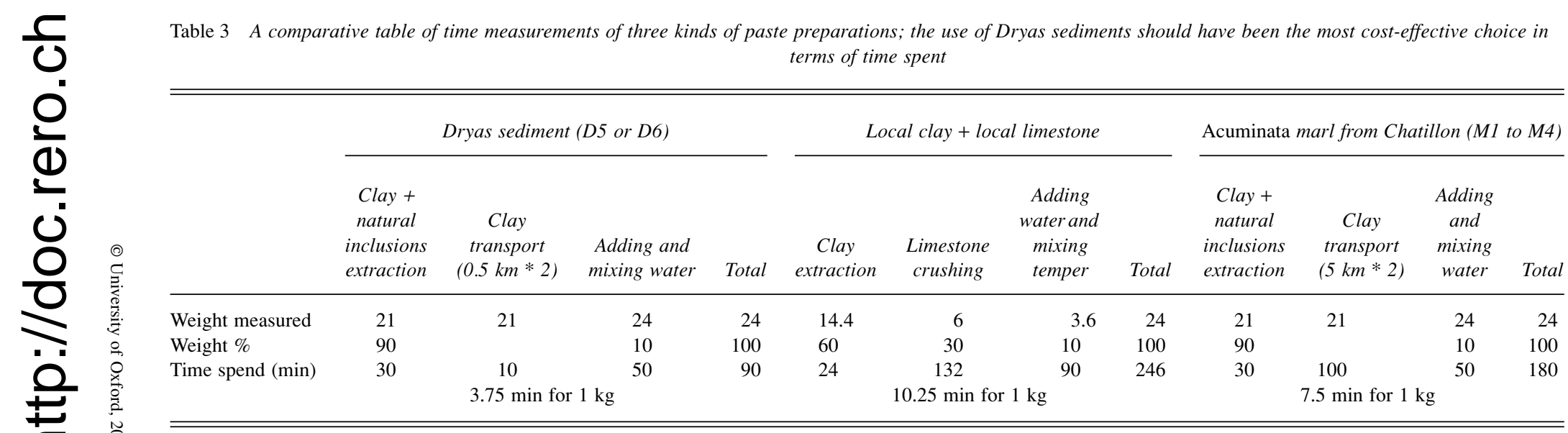


The quantity of carbonate in the matrix and the high proportion of inclusions (natural or added) are largely responsible for the low plasticity of these raw materials. As a result, these raw materials are difficult to use for pottery manufacture. The high proportion of inclusions may cause difficulty during forming, notably when joining rings.

Textural characteristics are heterogeneous in the different samples of Acuminata marls (Martineau 2000a). Samples such as M2 and M4.1, with few inclusions, allowed the production of pottery without too many problems. Samples M2 and M4.1 have a better workability than the other Acuminata marl samples.

The forming experiments highlighted differences between the Dryas sediments and the Acuminata marls. It was significantly more difficult to produce pottery using the Dryas sediments, notably with sample D6. The shaping process had to be completed very quickly because, for this sample, the drying process of the surface junction was very fast. This sediment has a thixotropic behaviour. The plasticity of the paste is increased by adding water, but if too much water is added, this paste loses its coherence and collapses. This problem is less often encountered with the Acuminata raw material.

The mineralogical analyses of the raw materials will allow the quantification and qualification of the differences between the two pastes in the forming process. It could be interesting to know why these raw materials, in particular, were used and perhaps even selected. There are many reasons for such choices: time spent, transport distance, the weight of heavy raw materials, cultural and pottery traditions and know-how, mechanical forming constraints such as workability, and firing or functional constraints. Such parameters should be analysed and quantified. Here, we propose to explore some of them, in particular the mineralogical, petrographic, textural and chemical characteristics of raw materials. These analyses were carried out on the natural samples (M1, M2, M3, M4.1, M4.3, M4.4, D5 and D6; Table 2, Fig. 4) as well as on the archaeological ones.

\section{METHODOLOGICAL AND ANALYTICAL CHOICES}

The methodological techniques are detailed in Appendix B. One of the key parameters for shaping a pottery body is the plasticity of the paste. Therefore, paste viscosity measurements seem to be a straightforward way of comparing the quality of different sediments for their use as pottery raw materials. The viscosity of a paste, however, is not only dependent on the physical and chemical properties of the solid, but also on the water/solid ratio, the water chemistry, the curing conditions and so on, parameters that remain unknown for the pastes used by the Neolithic potters. Therefore, the experiments only approximate the archaeological conditions. As a consequence, we have focused our analyses on the properties of the solid raw materials that may influence plasticity; for example, the sediment mineralogical composition (type and quantity of clay minerals) and its grain-size distribution.

Plasticity - the key parameter for the shaping of ceramic bodies-is, among others, a function of the mineralogical composition of the raw material. It is roughly proportional to the amount of clay minerals, especially of swelling types, in the sub-micron fraction. Therefore, physical characterization of the raw materials by X-ray diffraction (XRD), the Rietveld method and grain-size analysis should give independent, quantitative proof of the raw materials' plasticity and help to reinforce the qualitative results obtained from the manufacturing experiments.

To avoid confusion in the terminology, we would like to recall the distinction between the mineralogical and size-related use of the word 'clay'. In the classification scheme for grain 


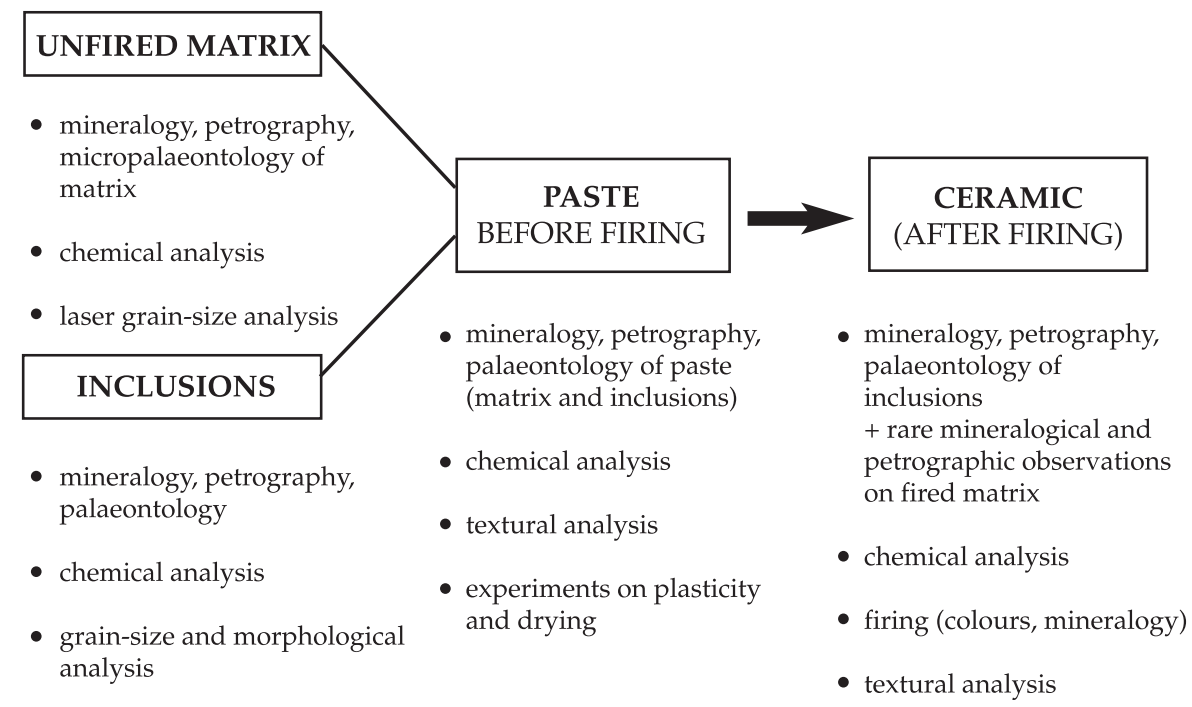

Figure 7 The correspondence between analyses applied to matrix and to inclusions, and the related steps of the 'chaîne opératoire'. Laser grain-size analyses cannot be performed after firing. Firing modifies the mineralogical information; for example, some clay minerals are altered.

size, the word 'clay' is used for the grain-size fraction $<2 \mu \mathrm{m}$ of sediment, independently of the nature of the minerals. Mineralogically, clay minerals (illite, kaolinite, chlorite and smectite, among others) are a subgroup of the phyllosilicate group. Although clay minerals have often grain sizes $<2 \mu \mathrm{m}$, their size is not limited to this fraction. Moreover, many minerals can have a size $<2 \mu \mathrm{m}$ without being clays.

Light optical, X-ray diffraction, grain-size distribution and calcimetric analyses were performed on the raw sediments. Figure 7 summarizes the different techniques applied, and their relations with the stages of the pottery production 'chaîne opératoire'. It is obvious that the laser-based grain-size analyses can only be used for the loose unfired raw materials but not for the fired clays.

\section{RESULTS OF NATURAL SEDIMENT ANALYSES}

\section{Grain-size analyses}

Samples were sieved into two fractions, with a cut-off point at $2 \mathrm{~mm}$. Analyses were performed on the fraction below $2 \mathrm{~mm}$. Table 4 gives percentages for the different grain-size classes. The Acuminata marls contain from 2.3 to 3.3 vol\% clay (0-2 $\mu \mathrm{m}$; samples M1-M4). The Dryas sediments show a higher proportion of clay fraction $(7.1 \mathrm{vol} \%$ for sample D5 and 19.6 vol\% for sample D6). In all samples, the fine silt $(2-20 \mu \mathrm{m})$ proportion is weak, except in sample D6 (main grain-size fraction with $39.9 \mathrm{vol} \%$ ).

In sample D5, gravel (>2 mm) represents the main grain-size fraction (25.2 vol\%). In the four Acuminata marl samples (M1-M4), the main grain size is gravel (>2 mm; 38.9-43.4 vol\%), except in sample M2, where the main fraction is coarse sand $(200-2000 \mu \mathrm{m} ; 30.3 \mathrm{vol} \%)$.

In short, global grain-size analyses show that the amount of the finest fraction is higher in the Dryas sediments than in the Acuminata marls (Tables 4 and 5). Moreover, a lot of natural 
Table 4 The bulk distribution of grain-size fractions in vol\%

\begin{tabular}{lcccccc}
\hline \hline Sample & $\begin{array}{c}\text { Clay, } \\
0-2 \mu m(\%)\end{array}$ & $\begin{array}{c}\text { Fine silt, } \\
2-20 \mu m(\%)\end{array}$ & $\begin{array}{c}\text { Coarse silt, } \\
20-50 \mu m(\%)\end{array}$ & $\begin{array}{c}\text { Fine sand, } \\
50-200 \mu m(\%)\end{array}$ & $\begin{array}{c}\text { Coarse sand, } \\
200-2000 \mu m(\%)\end{array}$ & $\begin{array}{c}\text { Gravels }> \\
2000 \mu m(\%)\end{array}$ \\
\hline M1 & 2.3 & 10.3 & 12.2 & 15.6 & $\mathbf{1 8 . 6}$ & $\mathbf{4 0 . 8}$ \\
M2 & 2.7 & 13.3 & 9.8 & 19.3 & $\mathbf{3 0 . 3}$ & $\mathbf{2 4 . 5}$ \\
M3 & 3.2 & 13.1 & 12.4 & 10.5 & $\mathbf{2 1 . 8}$ & $\mathbf{3 8 . 9}$ \\
M4 & 2.5 & 10.7 & 9.6 & 9.9 & $\mathbf{2 3 . 8}$ & $\mathbf{4 3 . 4}$ \\
D5 & 7.1 & 19.5 & 18.8 & $\mathbf{2 5 . 1}$ & 4.2 & $\mathbf{2 5 . 2}$ \\
D6 & 19.6 & $\mathbf{3 9 . 9}$ & $\mathbf{2 7 . 4}$ & 8.9 & 0.2 & 3.9 \\
\hline \hline
\end{tabular}

Table 5 Laser grain-size analysis results; the vol\% of the fraction $<2 \mu \mathrm{m}$ and grain-size populations in vol\%

Laser grain size

Granulometric populations $<2 \mathrm{~mm}$ (vol\%)

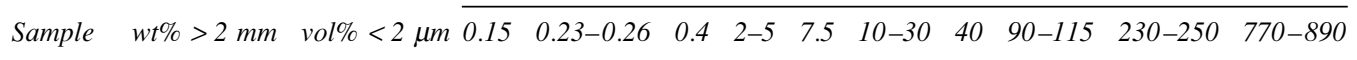

\begin{tabular}{lrrrrrrrrrrrrr}
\hline M1 & 62.9 & 4 & 0 & 1 & 0 & 10 & 0 & 14 & 25 & 15 & 10 & 25 \\
M2 & 37.7 & 4 & 0 & 1 & 0 & 9 & 0 & 15 & 11 & 17 & 16 & 31 \\
M3 & 59.9 & 5 & 0 & 2 & 0 & 9 & 0 & 28 & 12 & 9 & 12 & 27 \\
M4 & 66.9 & 4 & 0 & 1 & 0 & 7 & 0 & 22 & 12 & 10 & 15 & 34 \\
D5 & 38.8 & 9 & 0 & 2 & 0 & 30 & 0 & 13 & 21 & 28 & 6 & 0 \\
D6 & 6.0 & 20 & 1 & 0 & 4 & 40 & 2 & 33 & 12 & 7 & 0 & 0 \\
\hline
\end{tabular}

inclusions (gravels, 24.5-43.4 vol\%) are present in the Acuminata marls and in sample D5 (Dryas sediments), whereas they are rare in sample D6, which can be found close to the lake dwellings.

\section{Grain-size distribution curves}

The grain-size distribution curves are all of polymodal type. Samples M1-M4 show similar curves, characterized by the occurrence of a grain-size population whose mode is between 770 and $890 \mu \mathrm{m}$, not found in samples D5 and D6 (Table 5). These two samples also show higher proportions of particles $<2 \mu \mathrm{m}$, with a maximum of $20 \%$ in volume for sample D6 (Dryas sediment from the lake of Chalain), which is the sample with the lowest proportion of particles $>2 \mathrm{~mm}$ (Table 5).

After analysis by a smoothed second derivative method, 10 well-differentiated grain-size populations can be distinguished: $0.15 \mu \mathrm{m}, 0.23-0.24 \mu \mathrm{m}, 0.4 \mu \mathrm{m}, 2-5 \mu \mathrm{m}, 7.5 \mu \mathrm{m}, 10-30$ $\mu \mathrm{m}, 40 \mu \mathrm{m}, 90-115 \mu \mathrm{m}, 230-250 \mu \mathrm{m}$ and $770-890 \mu \mathrm{m}$. Table 5 shows the proportions of these 10 populations in samples M1-D6. These results show that samples D5 and D6 clearly differ from samples M1-M4 as the $2-5 \mu \mathrm{m}$ grain-size population prevails, and the $230-250$ $\mu \mathrm{m}$ and $770-890 \mu \mathrm{m}$ grain-size populations are either weakly represented or absent in these two samples. Moreover, the data in Table 5 also show that sample D5 differs from sample D6, 
as the $0.15 \mu \mathrm{m}, 2-5 \mu \mathrm{m}$ and $7.5 \mu \mathrm{m}$ grain-size populations only occur in sample D6, where the $0.23-0.26 \mu \mathrm{m}$ grain-size population does not occur.

\section{Mineralogical composition (XRD)}

The mineralogical assemblages found in the two raw materials are similar, but the individual phases occur in different proportions. The main minerals are calcite and quartz, whereas ankerite $\left(\mathrm{CaFe}\left(\mathrm{CO}_{3}\right)_{2}\right)$ is only present in three samples (M1, M2 and D6; see Table 6). Clay minerals were identified in the patterns obtained from the bulk analysis.

The XRD patterns from the clay fraction allowed a better identification and quantification of the clay minerals present. Illite and expandable clay minerals were identified in all samples from their (001) reflections at $10 \AA$ and about 12-13 $\AA$, respectively, in XRD patterns obtained from the air-dried samples. The shift of the basal reflections of the expandable fraction to 13.7 $\AA$ and $17 \AA$ after glycolation of the sample, and to $10 \AA$ after heating, may indicate the presence of irregularly interstratified mixed layers, such as smectite and smectite-illite. Chlorite is present in samples M3, D5 and D6 - that is, in oncoid facies of the Acuminata marls (M3) and in the Dryas sediments - and in a smaller proportion in sample M2 (Table 6). It is characterized by the (002) reflection at $7 \AA$ in patterns from air-dried, glycolated and heated samples. The (001) reflection at $14 \AA$ is difficult to characterize because of the presence of expandable clay. The hydrate-hydrazine treatment performed on samples D5 and D6 confirms that the $7 \AA$ reflection can be attributed to the presence of chlorite, and that these samples contain no kaolinite.

The relative abundance of each clay mineral in the clay fraction was semi-quantitatively estimated, using peak intensity ratios (Table 6). The expandable clay mineral (smectite and mixed layer) content in Acuminata marls (M1, M2 and M4) is relatively high, representing between $34 \%$ and $48 \%$ of the total clay minerals. The exception is sample M3 (oncoid facies), with only $19 \%$ of expanding clay minerals, but with $30 \%$ chlorite. The marly Dryas limestone from the lake of Chalain (D6) is characterized by $90 \%$ non-expandable clays, such as illite and chlorite (Table 6).

\section{Mineralogical quantification (Rietveld method and calcimetry)}

As the chemical results for the sediments have already been discussed and developed above, we will simply recall their main characteristics here. The Acuminata marls and Dryas sediments are both very rich in $\mathrm{CaO}$ (Fig. 2, Appendix A).

All Rietveld refinements converge and the residuals are in the expected range, as indicated by the $\chi^{2}$ value [(measured residual/expected residual $)^{2}$ ], which is between 1.5 and 1.8 (Table 6). The calcite content in all samples is high, between 68.4 and $88.5 \mathrm{wt} \%$ in the Acuminata marl samples (M1-M4) and between 57.6 and $81.7 \mathrm{wt} \%$ in the two Dryas samples (D5 and D6). The ankerite contents are between 4 and $7 \mathrm{wt} \%$. The sum of calcite and ankerite obtained from the Rietveld refinement is within 10 rel.\% of the carbonate content determined by calcimetry, with the exception of sample D5. The discrepancies may be explained by the heterogeneous nature of the samples, the fact that all $\mathrm{CO}_{2}$ from the calcimetry analyses is attributed to calcite, and errors related to the refinement process ( 5 rel.\%).

The illite concentration for sample M2 is $15 \mathrm{wt} \%$ (Table 6), but the finest grain-size fraction in the same sample represents only $2.7 \mathrm{vol} \%$ of the whole sample (Table 4). The weight and volume percentages are comparable in these samples, because all phases have nearly the same density. This is a clear indication that most of the illite minerals and white mica crystals in this 
Table 6 Qualitative XRD results and mineralogical quantitative measurements by the Rietveld method and calcimetry

\begin{tabular}{|c|c|c|c|c|c|c|c|c|c|c|c|c|c|c|c|c|c|c|}
\hline \multirow[b]{2}{*}{ Sample } & \multicolumn{4}{|c|}{ XRD bulk data } & \multicolumn{4}{|c|}{$X R D$ clay fraction $(\%)$} & \multirow[b]{2}{*}{$\begin{array}{c}\text { Calcimetry } \\
\mathrm{CaCO}_{3} \\
(w t \%)\end{array}$} & \multicolumn{9}{|c|}{ Rietveld method } \\
\hline & Calcite & Ankerite & Quartz & Clays & Illite & Chlorite & Smectite & $\begin{array}{l}\text { Illite/smectite } \\
\text { mixed layer }\end{array}$ & & $\begin{array}{c}\text { Calcite } \\
(w t \%)\end{array}$ & $\begin{array}{c}\text { Error } \\
(\%)\end{array}$ & $\begin{array}{l}\text { Illite } \\
(w t \%)\end{array}$ & $\begin{array}{c}\text { Error } \\
(\%)\end{array}$ & $\begin{array}{c}\text { Quartz } \\
(w t \%)\end{array}$ & $\begin{array}{c}\text { Error } \\
(\%)\end{array}$ & $\begin{array}{c}\text { Ankérite } \\
(w t \%)\end{array}$ & $\begin{array}{c}\text { Error } \\
(\%)\end{array}$ & Chi-squared \\
\hline M1 & $x \times x$ & $x$ & $x$ & $x$ & 51 & 0 & 24 & 24 & 81.3 & 77 & 1.11 & 5.4 & 1.5 & 10.6 & 0.34 & 7 & 0.78 & 1.73 \\
\hline M2 & $x x x$ & $\times$ & $\times$ & $\times$ & 59 & 7 & 8 & 26 & 68.4 & 59.4 & 1.04 & 15 & 1.19 & 20.8 & 0.5 & 4.8 & 0.72 & 1.77 \\
\hline M3 & $x \times x$ & & $\times$ & $x$ & 51 & 30 & 5 & 14 & 81.5 & 89 & 1.1 & 5.4 & 1.13 & 5.4 & 0.29 & - & - & 1.6 \\
\hline M4 & $x x x$ & & $\times$ & $\times$ & 58 & 2 & 14 & 26 & 88.5 & 88.9 & 0.78 & 6.1 & 0.8 & 4.9 & 0.18 & - & - & 1.52 \\
\hline D5 & $x \times x$ & & $x \times$ & $x$ & 30 & 41 & 25 & 5 & 57.6 & 66.4 & 0.81 & 12.5 & 1.01 & 21.1 & 0.34 & - & - & 1.78 \\
\hline D6 & $x x x$ & $x$ & $x x x$ & $\times$ & 48 & 42 & 7 & 3 & 81.7 & 83.6 & 0.76 & 3.7 & 0.67 & 8.6 & 0.18 & 4 & 0.53 & 1.55 \\
\hline
\end{tabular}

Table 7 A comparative table of the main characteristic parameters of the Dryas sediments and Acuminata marls: the grain size of the Dryas sediments is smaller, but most of this fraction is composed of quartz and calcite; natural oyster inclusions are present in Acuminata marls

\begin{tabular}{lll}
\hline \hline & Dryas sediments (D5 and D6) & Acuminata marls (M1-M4) \\
\hline Main minerals & Calcite and quartz & Calcite \\
Main mineral clays & Illite and chlorite & Illite, smectite and illite/smectite mixed layer \\
Main granulometric fractions & Clay and silt & Coarse sand and gravels \\
Main minerals in matrix & Illite $>2 \mathrm{~mm}$ for D5; calcite and quartz $<2 \mathrm{~mm}$ for D6 & Illite $>2 \mathrm{~mm}$ for M2 \\
Coarse aplastic inclusions & Rare or few natural inclusions & The main granulometric fraction consists of natural inclusions \\
\hline \hline
\end{tabular}


sample are larger than $2 \mu \mathrm{m}$, which is confirmed by thin-section analysis, where mica crystals of up to $150 \mu \mathrm{m}$ were observed. The same observation is valid for sample D5. This sample contains $12.5 \mathrm{wt} \%$ illite (Table 6), but its finest grain-size fraction $(<2 \mu \mathrm{m})$ represents only $7.1 \mathrm{vol} \%$ of the bulk (Table 4). In this case, petrographic observations reveal the presence of large white mica crystals $(<100 \mu \mathrm{m})$. In sample D6, the situation is exactly the opposite: the illite concentration is only $3.7 \mathrm{wt} \%$ (Table 6), but the finest grain-size fraction represents 19.6 vol\% of the bulk (Table 4). The difference may be explained by the contribution of non-clay minerals, such as quartz and carbonates, to the clay fraction. This result could very well explain the differential plastic behaviours of pastes during the forming process.

\section{DISCUSSION}

Table 7 summarizes the main characteristics of the marly Dryas limestones and the Acuminata marl sediments. Expanded clay minerals are only present in Acuminata marls. The grain size is lower in the marly Dryas limestones than in the Acuminata marls, but the fraction $<2 \mu \mathrm{m}$ is mainly represented by quartz and calcite. Natural aplastic inclusions are very abundant in Acuminata marls, whereas they are rare in Dryas sediments (Table 7).

Surprisingly, for both the Acuminata marls and the Dryas sediments, analyses show that the outcrops exploited by the Neolithic potters were not the best adapted for pottery making. Experiments and analyses suggest that D5 would be more suitable than D6, yet pottery fabric group B corresponds better, petrographically and chemically, with D6 (Fig. 2). In the same way, analyses show that M4.1 has the same chemical, palaeontological and petrographic characteristics as pottery fabric group A, whereas other samples share only the same petrographic and palaeontological characterization. Analyses and experiments suggest that M2 is a more suitable outcrop than M4.1 for pottery making, yet the Neolithic potters did not exploit it. One possible reason is that outcrop M2 is almost $10 \mathrm{~km}$ from lake-dwelling sites.

The lake of Chalain is located in an area where argillaceous sediments are rarely of good quality for pottery making (due to the high percentage of $\mathrm{CaO}$ and the low percentage of mineralogical clay). In this geological context, the sediments used by the potters of the lake dwellings represent extreme raw materials due to their very high percentage of calcium carbonate, their high inclusion content and their very low proportion of clay minerals. The $\mathrm{CaO}$ is higher in Dryas group $\mathrm{B}$ than in Acuminata group A, and $\mathrm{SiO}_{2}, \mathrm{Al}_{2} \mathrm{O}_{3}, \mathrm{~K}_{2} \mathrm{O}$ and $\mathrm{Fe}_{2} \mathrm{O}_{3}$ are lower in group $\mathrm{B}$ than in group A. High amounts of $\mathrm{CaO}$ and discrepancies in the $\mathrm{SiO}_{2}$, $\mathrm{Al}_{2} \mathrm{O}_{3}$ and $\mathrm{K}_{2} \mathrm{O}$ compositions could explain the differential plastic behaviours observed between the two sediment groups.

High lateral facies variability of clay mineral proportions was observed in the Acuminata formation in Burgundy (Dumanois 1982) and in our Jura samples. Such high variability might explain the difference in plasticity and better workability of M2 and M4.1.

Archaeological experiments may be considered to be subjective. Nevertheless, our analytical results confirm the experiments using these raw materials in pottery forming. The sediment parameters influencing the plasticity and drying behaviour of the paste are better when using the Acuminata marls than the Dryas sediments. The D6 fraction $<2 \mu \mathrm{m}$ is mainly constituted of quartz and calcite. The high drying speed observed in experiments with Dryas sediments is a consequence of the high proportion of carbonate and quartz and the low amount of expandable clays in the finest grain-size fraction $(<2 \mu \mathrm{m})$. In marls, the presence of detrital elements plays a role in the plasticity: the higher the proportion of detrital fragments, the lower is the plasticity (Rémont 1967). 
The use of Dryas sediments for the manufacture of earth structures used as fireplaces in houses was not a problem, because they do not need to be fired. Moreover, their forming is not comparable to that of pottery. The principal technical advantage of using Acuminata marls may be the presence of natural fossil oyster inclusions in the sediment, which represent natural inclusions in the matrix (Table 7). Can time be saved by using a more distant sediment with natural inclusions rather than a nearer clay without inclusions? Effectively, the time saved in paste preparation could be another reason to explain the transport of the Acuminata marls. The amount of time required when using a local clay, mixed with a local hand-crushed limestone, is a third higher than that required, including transport, when using Acuminata marls with natural inclusions. The Neolithic potters of Chalain would have had the choice between these two paste preparations. Nevertheless, the Dryas sediments are located immediately around the lake dwellings, at a shorter distance than the Acuminata marls (Fig. 4), and they contain natural inclusions. The time spent on the acquisition of this sediment is half that required for the Acuminata marls, and three time less than that needed for local clay with added limestone (Table 3). Nevertheless, the Acuminata marls, which are located $5 \mathrm{~km}$ from the dwellings, were used more often in two successive periods (Figs 4 and 6). Could this be a strong indication that the oyster-bearing raw material had some technical advantage that made the longer transport distance worthwhile?

Evolution in the use of raw materials obviously led to technical improvements in the production process. However, social and cultural aspects could also have played a role. During this period, potters also tried out Dryas sediments and made $26.9 \%$ of their pottery with this raw material over a short period of time (Fig. 6). Then, an immigrant population arrived at the lake of Chalain (Pétrequin 1993, 1997a,b, 1999; Arbogast et al. 1995, 1996; Pétrequin et al. 1998). This new population, from the Ferrières/Clairvaux culture (Giligny 1994, 1997), brought with them their own pottery, manufactured using a raw material consisting of a micaceous matrix containing granite rock fragments (petrographic groups 1, 3 and 4; Fig. 6). This kind of raw material is not present in the surrounding area and is only found at a distance of at least 50-60 km or more (Martineau 2000a; Martineau et al. 2000; Di Pierro and Martineau 2002a,b). The matrix of this pottery is clay rich, and was certainly better suited to pottery making than all the carbonate raw materials found around the lake of Chalain. The Neolithic potters must have known what 'good pottery raw materials' look and feel like. This technocultural heritage may have been the driving force that encouraged the Ferrières/Clairvaux potters to look for better raw materials in their new environment. For a short time, this new population used, in small proportions (12.5\%), the same Dryas sediments as the Horgen culture, before turning their attention to new raw materials, such as the Acuminata marls (Fig. 6).

It is somewhat surprising that the search did not end at the Dryas sediment outcrop represented by sample D5, which is clearly better suited for pottery making than D6 and lies closer to the dwellings than the Acuminata marls (Fig. 4). Similar observations can be made for the Oxfordian sediments (group 10, Fig. 6), found $1.5 \mathrm{~km}$ from the Neolithic sites (Fig. 4), which were often used during the Horgen and Middle Clairvaux cultures (Fig. 6), but not during the Ferrières/Clairvaux and Early Clairvaux cultures.

When discussing this complex question, all parameters have to be taken into account. In the case studied here, it seems that the low proportion of clay minerals in the Dryas sediment matrix and the natural oyster inclusions in the Acuminata marls could be among the main reasons for their selection.

The complexity of the archaeological situation suggests that a combination of social, cultural and also technical factors may well have motivated the potters' behaviour at Chalain, between 
c. $3169 \mathrm{BC}$ and $2980 \mathrm{BC}$ (calendar years). Changes in pottery raw materials and style may sometimes be induced by cultural factors, with or without technical advantages. In this case, both technical data and sociocultural factors, simultaneously, are the driving forces for change (Martineau 2000a). As explained by Sillar and Tite (2000), interpretation of technical results cannot be dissociated from the study of social context. Our research shows the complexity of the problem and demonstrates the need for a series of analyses and experiments, which must be embedded in the archaeological and socio-economic context.

\section{CONCLUSIONS AND PERSPECTIVES}

We have shown that differences in the workability of two pastes during experimental pottery making can be quantitatively explained by chemical and mineralogical analyses of the raw materials. We focused our study on the raw material factors affecting paste plasticity. Experiments also show differences in other properties, such as the drying behaviour of the paste. The factor that most affects the drying behaviour is the clay mineral content, but pore-size distribution in the paste must also be taken into account. Oyster shells are known to have a high pore volume. Paste porosity measurements should provide more quantitative proof of the technical advantage of the Acuminata marls over the Dryas sediments. In the less clayey matrices, the increase in bulk porosity due to the porosity of oyster inclusions could be another important technical parameter.

We have focused our attention on factors influencing the production of pottery more than on those concerning its use and functional characteristics. It has been argued that shell inclusions, due to their platy shape, improve thermal shock resistance (Steponaitis 1984). Many other parameters, such as the increase in workability using shell or limestone, the geological environment, social factors and even the nature of the matrix (calcareous or non-calcareous), should be taken into account in discussing this question (Tite and Kilikoglou 2002). Tests of mechanical strength and thermal shock resistance should be performed on pottery from Chalain.

The results obtained in this study should be confirmed by further analysis. In order to characterize and quantify the nature of each grain size, it will be necessary to sieve sediments and extract each grain-size fraction for XRD and geochemical determinations. The objective would be to estimate the proportion of each mineral in each fraction.

Moreover, textural analyses of archaeological pottery will allow us to evaluate precisely the proportion of inclusions, and compare this amount with that found in natural sediments. The Neolithic potters could have sieved the sediments, or chosen outcrops containing a lower proportion of inclusions (Martineau 2000a). It will also be very interesting to measure mechanical properties, such as plasticity and drying speed, in order to quantify the differences in workability observed experimentally between the Dryas sediments and the Acuminata marls. The comparison of these mechanical properties for the two types of sediments will allow us to understand better the differences observed through experimental practice and mineralogical analyses.

To understand changes in pottery technique, elements such as the environmental context, sociocultural factors, pottery forming, past technical knowledge and raw materials used must all be taken into account by an experimental approach, and by physical and mineralogical analyses. All of these aspects must be embedded in well-known and well-studied archaeological contexts. In short, it is necessary to multiply observations and results before drawing conclusions about tendencies or theories. The best method would be to obtain enough data from 
a series of case studies covering different periods and geographical areas, in order to construct new theories of technical, historical and social changes and material culture evolution. In this paper, we have documented the adaptations of the potter communities to their environment. The carbonate-rich geological context limited their raw material choices. Nevertheless, the archaeological data show clearly a succession of changes during the two centuries studied. We have documented these changes and discussed their implications. Further studies in other contexts will enrich our discussion of the underlying reasons for these raw material changes or choices.

\section{ACKNOWLEDGEMENTS}

We would like to thank A. Boullier (Department of Geosciences, University of FrancheComté, France) and F. Convertini (INRAP, Montpellier, France), who have contributed to the characterization of some raw materials. We would also like to thank P. Pétrequin (laboratory of Chrono-écologie, CNRS/University of Franche-Comté, Besançon, France), who is in charge of the research program on the lake-dwelling sites of Chalain and Clairvaux (Jura, France). Finally, we would like to thank M. Maggetti and V. Serneels (Department of Geosciences/ Mineralogy and Petrography, University of Fribourg, Switzerland), who reviewed this paper.

This paper was written during the postdoctoral fellowship of R. Martineau, funded by the Fyssen Foundation (Paris).

We also would like to thank C. Chateau-Smith for proofreading this paper.

\section{REFERENCES}

Allen, C., 1991, Thin sections of Bronze Age pottery from the East Midlands of England, in Recent developments in ceramic petrology (eds. A. Middleton and I. Freestone), 1-9, British Museum Occasional Paper, 81, London.

Arbogast, R.-M., Magny, M., and Pétrequin, P., 1995, Expansions et déprises agricoles au Néolithique: populations, cultures céréalières et climat dans la combe d'Ain (Jura, France), in L'homme et la dégradation de l' environnement, XVe Rencontres Internationales d'Archéologie et d'Histoire d'Antibes (ed. S. Van der Leeuw), 20-41, APDCA, Antibes.

Arbogast, R.-M., Magny, M., and Pétrequin, P., 1996, Climat, cultures céréalières et densité de population au Néolithique: le cas des lacs du Jura français de 3500 à 2500 av. J.-C., Archäologisches Korrespondenzblatt, 26, 121-44.

Arnold, D. E., 1985, Ceramic theory and cultural process, Cambridge University Press, Cambridge.

Arnold, D. E., 2005, Linking society with the compositional analyses of pottery: a model from comparative ethnography, in Pottery manufacturing processes: reconstruction and interpretation (eds. A. Livingstone Smith, D. Bosquet and R. Martineau), 15-21, British Archaeological Reports, International Series 1349, Oxford.

Balfet, H., 1962, Céramique ancienne en Proche-Orient (Israël et Liban, VI-VIIème millénaires). Etude technique, unpubl. Ph.D. dissertation, Ethnologie; Micro-éditions, Archives et Documents, Institut d'Ethnologie du Musée de l'Homme, no. 6275802.

Bish, D. L., and Post, J. E., 1993, Quantitative mineralogical analysis using the Rietveld full-pattern fitting method, American Mineralogist, 78, 932-40.

Bonzon, J., 2003, Petrographical study of Neolithic ceramic from Arbon-Bleiche 3, (Canton of Thurgau, Switzerland), in Ceramic in the society, Proceedings of the 6th European Meeting on Ancient Ceramics, EMAC'01, Fribourg, 3-6 October 2001 (eds. S. Di Pierro, V. Serneels and M. Maggetti), 25-50.

Bossuet, G., Richard, H., Magny, M., and Rossy, M., 1997, Nouvelle occurence du Laacher See Tephra dans le Jura central. L'étang du Lautrey (France), Compte-Rendu de l'Académie des Sciences, Sciences de la terre et des planètes, 325, 43-8.

Bossuet, G., Ruffaldi, P., Magny, M., Richard, H., and Mouthon, J., 1996, Dynamique et approche quantitative des remplissages fini- et postwürmiens du bassin lacustre de Cerin (Jura, France), Bulletin de la Société Géologique de France, 167, 483-94.

Campy, M., 1982, Le Quaternaire franc-comtois. Essai chronologique et paléoclimatique, unpubl. Ph.D. dissertation, Faculté des Sciences et Techniques de 1'Université de Franche-Comté. 
Chauve, P., Campy, M., Contini, D., Martine, J., Petitjean, E., and Sequeiros, F., 1993, Notice explicative et carte géologique de la France (1/50 000), feuille de Lons-le-Saunier (581), 2nd edn, Bureau de recherches géologiques et minières, Orléans.

Colas, C., 2000, Savoir-faire technique et reconstitution des chaînes opératoires des potiers au Néolithique moyen II dans la moitié nord de la France: étude techno-typologique, unpubl. Ph.D. dissertation, UFR des Arts et Archéologie option Préhistoire, Anthropologie, Ethnologie, Université de Paris I-Sorbonne.

Constantin, C., 1985, Fin du Rubané, céramique du Limbourg et post-rubané. Le Néolithique le plus ancien en Bassin parisien et en Hainaut, British Archaeological Reports 273, 2 vols, Oxford.

Constantin, C., and Courtois, L., 1985, Le matériau céramique comme caractéristique culturelle. L'exemple du dégraissant pendant le Néolithique dans le Bassin-Parisien, in Etudes des céramiques en archéologie. Documents et travaux, 9, 19-26, I.G.A.L, Paris.

Contini, D., 1970, L'Aalénien et le Bajocien du Jura franc-comtois. Étude stratigraphique, Les Belles Lettres, Paris (Annales scientifiques de l'Université de Besançon, 3ème série, fasc. 11).

Courtois, L., 1971, Description physico-chimique de la céramique ancienne: la céramique de Chypre au Bronze récent, unpubl. Ph.D. dissertation, Université de Clermont-Ferrand.

Cumberpatch, C. G., Griffiths, D. R., Kolb, C. C., Neff, H., Roux, V., and Stilborg, O., 2001, Comments on 'Technological choices in ceramic production', Archaeometry, 42(1), 1-76, 2000, in Archaeometry, 43, 269-88.

Di Pierro, S., 2002, Domestic production versus pottery exchange during the Final Neolithic: characterisation of the Auvernier-cordé ceramics from the Portalban and St. Blaise settlements, Western Switzerland, unpubl. Ph.D. dissertation, Université de Fribourg (Suisse), no. 1391, Iridea di F. Bugnone et C. Torino, Turin.

Di Pierro, S., 2003, Ceramic production technology and provenance during the Final Neolithic: the Portalban settlement, Neuchâtel Lake, Switzerland, Proceedings of the '4e colloque d'Archéométrie', GMPCA, La Rochelle, 24-28 April 2001, Revue d'Archéométrie, 27, 75-93.

Di Pierro, S. and Martineau, R., 2002a, Pottery tempering with Mont Blanc granite across the Jura belt during Swiss and French Final Neolithic, in 33rd International Symposium on Archaeometry, Amsterdam, April 2002, abstract, 75-6.

Di Pierro, S. and Martineau, R., 2002b, Pottery tempering with Mont Blanc granite across the Jura belt during French and Swiss Final Neolithic, in S. Di Pierro, Domestic production versus pottery exchange during the Final Neolithic: characterisation of the Auvernier-cordé ceramics from the Portalban and St. Blaise settlements, Western Switzerland, unpubl. Ph.D. dissertation, Université de Fribourg (Suisse), no. 1391, Iridea di F. Bugnone et C. Torino, Turin.

Dumanois, A., 1982, Les huîtres des marnes à Ostrea Acuminata et leur signification (Bajocien superieur de Bourgogne, France), unpubl. Ph.D. dissertation, Institut des Sciences de la Terre de l'Université de Dijon.

Echallier, J.-C., and Courtin, J., 1994, Approche minéralogique de la poterie du Néolithique ancien de La Baume Fontbrégoua à Salernes (Var), Gallia Préhistoire, 36, 267-97.

Enay, R., 1966, L'Oxfordien dans la moité sud du Jura français: étude stratigraphique, Nouvelles archives du Muséum d'Histoire naturelle de Lyon, fasc. 8, Société Anonyme de l'Imprimerie A. Rey, Lyon.

Gaillard, C., 1983, Les Biohermes à Spongiaires et leur Environnement dans l'Oxfordien du Jura Méridional, Documents des Laboratoires de Géologie, Université Claude-Bernard, Lyon, no. 90.

Giligny, F., 1994, Variabilité et transferts techniques dans le Jura à la fin du IVe et au IIIe millénaires av. J.-C., in Terre cuite et société. La céramique, document technique, économique, culturel, XIVe Rencontres Internationales d'Archéologie et d'Histoire d'Antibes, 363-80, Juan-les-Pins, APDCA.

Giligny, F., 1997, La céramique de Chalain 3, in Les sites littoraux néolithiques de Clairvaux-les-Lacs et de Chalain (Jura). III, Chalain station 3, 3200-2900 av. J.-C., (ed. P. Pétrequin), vol. 2, 327-70, Maison des Sciences de 1'Homme, Paris.

Girardot, L. A., 1890-6, Matériaux pour la géologie du Jura: Jurassique inférieur lédonien. Coupes des étages inférieurs du système jurassique dans les environs de Lons-le-Saunier, avec la description et la faune de chaque étage, des considérations sur le régime de la mer jurassique, Lons-le-Saunier.

Gosselain, O., 1994, Skimming through potter's agendas: an ethnoarchaeological study of clay selection strategies in Cameroon, in Society, culture, and technology in Africa (ed. S. Terry Childs), 99-107, MASCA Research Papers in Science and Archaeology (Supplement to volume 11), Philadelphia.

Gosselain, O., 1995, Identités techniques. Le travail de la poterie au Cameroun méridional, unpubl. Ph.D. dissertation, Faculté de Philosophie et Lettres, Université libre de Bruxelles.

Gosselain, O., and Livingstone Smith, A., 1995, The Ceramics and Society Project: an ethnographic and experimental approach to technological choices, 147-60, KVHAA Konferenser 34, Stockholm.

Guillaume, A., 1964, Notes de géologie jurassienne: 1, Bulletin de la Société d'Histoire Naturelle du Doubs, 66(3), 47-52. 
Guillaume, S., and Guillaume, A., 1965, Notice explicative et carte géologique de la France (1/50 000), feuille de Champagnole (XXXIII-26), Bureau de recherches géologiques et minières, Orléans.

Hultén, B., 1977, On ceramic technology during the Scanian Neolithic and Bronze Age, North European Archaeology 6, Institut d'Archéologie de l'Université de Stockholm, Stockholm.

Kolb, C. (ed.), 1989, Ceramic ecology 1988: current research on ceramic materials, British Archaeological Reports, S-513, Oxford.

Lacroix, M., Rodet, J., Wanq, H. Q., Maséi, N., and Dupont, J. P., 2000, Origine des matières en suspension dans un système aquifère karstique: apports de la microgranulométrie, Comptes Rendu de l'Academie des Sciences, Paris, 330, 347-54.

Latour, B., and Lemonnier, P. (eds.), 1994, De la préhistoire aux missiles balistiques. L'intelligence sociale des techniques, La Découverte, Paris.

Lavier, C., 1996, Dendrochronologie appliquée à l'Archéologie: élaboration d'une chronologie du chêne (Quercus sp.) pour le Néolithique à partir des sites lacustres de Clairvaux-les-Lacs et de Chalain (Jura, France), Mémoire de Diplôme d'Etudes Approfondies en Méthodes et Techniques Nouvelles en Sciences Humaines, option 'Histoire et Cultures des Sociétés Antiques (paléo-environnement)', Faculté des Lettres et Sciences Humaines, Université de Franche-Comté.

Lemonnier, P., 1986, The study of material culture today: toward an anthropology of technical systems, Journal of Anthropological Archaeology, 5(2), 147-86.

Lemonnier, P., 1993, Introduction, in Technological choices: transformation in material culture since the Neolithic (ed. P. Lemonnier), 1-35, Routledge, London.

Lesourd, S., 2000, Processus d'envasement d'un estuaire macrotidal: zoom temporel du siècle à l' heure; application à l'estuaire de la Seine, unpubl. Ph.D. dissertation, Université de Caen, France.

Livingstone Smith, A., 2000, Processing clay for pottery in northern Cameroon: social and technical requirements, Archaeometry, 42, 21-42.

Magny, M., 1991, Une approche paléoclimatique de l'Holocène: les fluctuations des lacs du Jura et des Alpes du Nord françaises, unpubl. Ph.D. dissertation, Université de Franche-Comté, France.

Magny, M., 1992, Sédimentation et dynamique de comblement dans les lacs du Jura au cours des 15 derniers millénaires, Revue d'Archéométrie, 16, 27-49.

Martineau, R., 1995, Approche expérimentale de la céramique néolithique. Le cas des sites de Chalain et de Clairvaux (Jura), unpubl. Masters dissertation, Université de Paris X-Nanterre, France.

Martineau, R., 2000a, Poterie, techniques et sociétés. Etudes analytiques et expérimentales à Chalain et à Clairvaux (Jura), entre 3200 et 2900 av. J.-C., unpubl. Ph.D. dissertation, UFR des Sciences de l'Homme, du Langage et de la Société, Archéologie-préhistoire, Université de Franche-Comté, Besançon, France.

Martineau, R., 2000b, Technologie céramique et chronologies néolithiques. Approche méthodologique à partir de l'exemple des sites de Chalain (Jura), in INTERNÉO 3-2000, Journée d'information du 2 décembre 2000, 10310, Association pour les Études Interrégionales sur le Néolithique (INTERNÉO), Paris.

Martineau, R., 2002, La fabrication des poteries du groupe de Clairvaux ancien (Jura), entre 3040 et 2980 av. J.-C. Expérimentation et analyse du façonnage et des traitements de surface, in Préhistoire et approche expérimentale (eds. L. Bourguignon, I. Ortega and M.-C. Frère-Sautot), 173-85, Collection préhistoire no. 5, ed. Monique Mergoil, Montagnac.

Martineau, R., and Maigrot, Y., 2004, Les outils en os utilisés dans la fabrication des poteries néolithiques de Chalain 4 (Jura). Expérimentation céramique et étude tracéologique, in Approches fonctionnelles en Préhistoire, Actes du XXVe Congrès préhistorique de France, 24-26 novembre 2000, Nanterre (eds. P. Bodu and C. Constantin), 83-95.

Martineau, R., and Pétrequin, P., 2000, La cuisson des poteries néolithiques de Chalain (Jura). Approche expérimentale et analyse archéologique, in Arts du feu et productions artisanales, XXe Rencontres Internationales d'Archéologie et d'Histoire d'Antibes, 21-23 octobre 1999 (eds. P. Pétrequin, P. Fluzin, J. Thiriot and P. Benoit), 337-58, APDCA, Juan-les-Pins.

Martineau, R., Convertini, F., and Boullier, A., 2000, Provenances et exploitations des terres à poterie des sites de Chalain (Jura), aux 31ème et 30ème siècles avant J.-C., Bulletin de la Société Préhistorique Française, 97(1), 5771.

Martineau, R., Convertini, F., and Boullier, A., in press, Les pâtes céramiques: natures, provenances et dynamiques évolutives, in Les sites littoraux néolithiques de Chalain et de Clairvaux (Jura), Du Ferrières au groupe de Clairvaux (3le et 30e siècles av. J.-C.) (eds. P. Pétrequin and A.-M. Pétrequin), vol. IV, ed. Maison des Sciences de l'Homme, Paris.

Matson, F. R., 1965, Ceramic ecology: an approach to the study of the early cultures of the Near East, in Ceramics and man (ed. F. R. Matson), 202-17, Aldine, Chicago. 
Mercader, J., Garcia-Heras, M., and Gonzalez-Alvarez, I., 2000, Ceramic tradition in the African forest: characterisation analysis of ancient and modern pottery from Ituri, D.R. Congo, Journal of Archaeological Science, 27, $163-82$.

Molinas, C., 1995, Typologie fonctionnelle des récipients céramiques en contexte d' habitat au Bronze final IIIb-Hallstatt ancien dans la moyenne vallé de l'Oise, unpubl. Masters dissertation, Université de Paris I-Sorbonne.

Morzadec, H., 1996, Pétro-archéologie des céramiques armoricaines du Néolithique à la fin de l'Age du Fer, Travaux du Laboratoire d'Anthropologie no. 41, unpubl. Ph.D. dissertation, Université de Rennes I.

Pétrequin, P., 1993, North wind, south wind. Neolithic technical choices in the Jura mountains, 3700-2400 B.C., in Technical choices: transformation in material cultures since the Neolithic (ed. P. Lemonnier), 36-76, Routledge, London.

Pétrequin, P. (ed.), 1997a, Les sites littoraux néolithiques de Clairvaux-les-Lacs et de Chalain (Jura), III, Chalain station 3, 3200-2900 av. J.-C., Maison des Sciences de l'Homme, Paris, 2 vols.

Pétrequin, P., 1997b, Histoire d'une migration réussie, L'Archéologue, 31, 42-6.

Pétrequin, P., 1999, Les lacs de Chalain et de Clairvaux: dynamique évolutive des styles céramiques et transferts de population, Gallia Préhistoire, 40, 134-40.

Pétrequin, P., Pétrequin, A.-M., Giligny, F., and Ruby, P., 1994, Produire pour soi, la céramique de Chalain 2 C au Néolithique Final, Bulletin de la Société Préhistorique Française, 91(6), 407-17.

Pétrequin, P., Arbogast, R.-M., Bourquin-Mignot, C., Lavier, C., and Viellet, A., 1998, Demographic growth, environmental changes and technical adaptations: responses of an agricultural community from the 32 nd to the 30th centuries bc, World Archaeology, 30(2), 181-92.

Regert, M., Dudd, S., Pétrequin, P., and Evershed, P., 1999, Fonction des céramiques et alimentation au Néolithique final sur les sites de Chalain. De nouvelles voies d'étude fondées sur l'analyse chimique des résidus organiques conservés dans les poteries, Revue d'Archéométrie, 23, 91-9.

Rémont, D., 1967, Quelques propriétés des sédiments argileux jurassiques. Essai de corrélations entre leurs caractéristiques géologiques et géotechniques, unpubl. Ph.D. dissertation, Université de Franche-Comté, Besançon.

Sénépart, I., and Convertini, F., 2003, Essai de caractérisation des productions céramiques cardiales du Baratin à Courthézon (Vaucluse). Le rôle du dégraissant dans la définition temporelle et spatiale des groupes culturels, in Temps et espaces culturels. Du $6^{\circ}$ au $2^{\circ}$ millénaire en France du Sud, Actes des IVe Rencontres Méridionales de Préhistoire Récente, Nîmes, 28-29 octobre 2000 (eds. J. Gascó, X. Gutherz and P.-A. de Labriffe), 83-97, Monographies d'Archéologie Méditerranéenne 15.

Sillar, B., and Tite, M. S., 2000, The challenge of 'technological choices' for materials science approaches in archaeology, Archaeometry, 42, 2-20.

Sillar, B., Livingstone Smith, A., and Pool, C. A., 2001, Comments on 'Technological choices in ceramic production'. Replies, Archaeometry, 42(1), 1-76, 2000, in Archaeometry, 43, 288-99.

Steponaitis, V. P., 1984, Technological studies of prehistoric pottery from Alabama: physical properties and vessel function, in The many dimensions of pottery (eds. S. E. Van der Leeuw and A. C. Pritchard), 81-127, University of Amsterdam, Amsterdam.

Taylor, J. C., 1991, Computer programs for standardless quantitative analysis of minerals using the full powder diffraction profile, Powder Diffraction, 6, 2-9.

Tite, M., 1999, Pottery production, distribution, and consumption. The contribution of the physical sciences, Journal of Archaeological Method and Theory, 6(3), 181-233.

Tite, M., and Kilikoglou, V., 2002, Do we understand cooking pots and is there an ideal cooking pot?, in Modern trends in scientific studies on ancient ceramics, 5th European Meeting on Ancient Ceramics (EMAC), Athens, 1820 October 1999 (eds. V. Kilikoglou, A. Hein and Y. Maniatis), 1-6, British Archaeological Reports, International Series 1011, Oxford.

Wang, H. Q., Dupont, J. P., Lafite, R., and Meyer, R., 1999, A differentiation method for separating a mixture of suspended particle size distributions, Hydrology and Earth System Sciences, 3(2), 177-85. 
APPENDIX A

Chemical data of Dryas and Acuminata pottery and sediments: $\mathrm{FeO}_{\text {tot }}$ as $\mathrm{Fe}_{2} \mathrm{O}_{3}$; oxides in wt $\%$; trace elements in ppm

\begin{tabular}{|c|c|c|c|c|c|c|c|c|c|c|c|c|c|c|c|c|c|c|c|c|c|c|c|c|c|}
\hline Sample & Location & $\begin{array}{l}\text { Pottery } \\
\text { group }\end{array}$ & $\mathrm{SiO}_{2}$ & $\mathrm{TiO}_{2}$ & $\mathrm{Al}_{2} \mathrm{O}_{3}$ & $\mathrm{Fe}_{2} \mathrm{O}_{3}$ & $\mathrm{MnO}$ & $\mathrm{MgO}$ & $\mathrm{CaO}$ & $\mathrm{Na}_{2} \mathrm{O}$ & $\mathrm{K}_{2} \mathrm{O}$ & $P_{2} O_{5}$ & $B a$ & $\mathrm{Cr}$ & $\mathrm{Cu}$ & $\mathrm{Nb}$ & $\mathrm{Ni}$ & $P b$ & $R b$ & $S r$ & $V$ & $Y$ & $Z n$ & $Z r$ & $S_{U M}$ \\
\hline M1 & Le Fied 52 & & 21.32 & 0.21 & 6.44 & 3.03 & 0.02 & 3.26 & 63.8 & 0.01 & 1.55 & 0.08 & 60 & 60 & 36 & 8 & 28 & 9 & 61 & 610 & 59 & 18 & 18 & 80 & 99.72 \\
\hline M2 & Fay en Montagne 79 & & 32.7 & 0.37 & 9.79 & 5.3 & 0.2 & 2.44 & 46.7 & 0.01 & 2.31 & 0.27 & 124 & 83 & 13 & 11 & 42 & 15 & 119 & 451 & 119 & 40 & 39 & 138 & 100.09 \\
\hline M2B & Fay en Montagne 79 & & 29.72 & 0.33 & 8.49 & 4.66 & 0.15 & 3.00 & 51.54 & 0.01 & 2.04 & 0.25 & 110 & 78 & 12 & 11 & 36 & 14 & 106 & 474 & 93 & 37 & 33 & 131 & 100.19 \\
\hline $\mathrm{M} 2 \mathrm{C}$ & Fay en Montagne 79 & & 25.8 & 0.28 & 8.19 & 3.81 & 0.11 & 3.56 & 55.63 & 0.01 & 2.06 & 0.15 & 75 & 65 & 13 & 10 & 37 & 7 & 93 & 510 & 86 & 26 & 29 & 102 & 99.6 \\
\hline M2D & Fay en Montagne 79 & & 14.36 & 0.15 & 4.95 & 4.02 & 0.04 & 1.65 & 73.66 & 0.01 & 1.00 & 0.18 & 44 & 54 & 15 & 6 & 31 & 12 & 36 & 451 & 79 & 30 & 28 & 70 & 100.02 \\
\hline M3 & La Marre $76-77$ & & 40.24 & 0.52 & 13.47 & 7.5 & 0.35 & 2.26 & 31.18 & 0.01 & 2.89 & 0.32 & 167 & 115 & 11 & 13 & 61 & 19 & 169 & 334 & 167 & 55 & 48 & 157 & 98.74 \\
\hline M3 bis & La Marre 76-77 & & 42.14 & 0.54 & 13.98 & 7.82 & 0.36 & 2.33 & 29.55 & 0.01 & 3.02 & 0.33 & 184 & 116 & 14 & 13 & 62 & 18 & 173 & 319 & 168 & 57 & 56 & 164 & 100.08 \\
\hline M4.1 & Chatillon 70 & & 31.03 & 0.4 & 12.65 & 10.39 & 0.08 & 2.38 & 41.22 & 0.01 & 1.72 & 0.29 & 163 & 115 & 12 & 13 & 59 & 25 & 111 & 233 & 176 & 76 & 408 & 125 & 100.17 \\
\hline M4.3 & Chatillon 72 & & 59.01 & 1.03 & 20.04 & 6.3 & 0.03 & 1.99 & 7.82 & 0.01 & 3.4 & 0.15 & 264 & 170 & 9 & 30 & 89 & 18 & 213 & 135 & 208 & 37 & 913 & 244 & 99.78 \\
\hline 14.4 & Chat & & & 0.14 & 4. & & 0.02 & 1.5 & 74.2 & 0 & 0.86 & 0.13 & 49 & 50 & 5 & 8 & 35 & 8 & 27 & 554 & 57 & 19 & 35 & 64 & 100.15 \\
\hline D5 & MLV & & 39.45 & 0.48 & 9.85 & 4.57 & 0.05 & 1.4 & 42.18 & 0.0 & 1.59 & 0.13 & 132 & 85 & 10 & 16 & 40 & 19 & 96 & 245 & 108 & 38 & 70 & 200 & 99.71 \\
\hline D6 & Lake of Chalain 36 & & 21.69 & 0.23 & 5.91 & 2.57 & 0.04 & 2.63 & 66.06 & 0.01 & 0.99 & 0.09 & 74 & 51 & 8 & 10 & 27 & 7 & 45 & 472 & 68 & 16 & 35 & 102 & 100.22 \\
\hline RM 2408 & & Group 12-1 & 32.34 & 0.47 & 13.86 & 3.23 & 0.08 & 1.54 & 46.1 & 0.01 & 1.69 & 0.3 & 177 & 86 & 16 & 14 & 51 & 12 & 72 & 431 & 101 & 29 & 91 & 124 & 99.62 \\
\hline M 2210 & & Group 12-2 & 33.92 & 0.6 & 16.38 & 4.05 & 0.09 & 1.71 & 39.81 & 0.0 & 2.03 & 1.33 & 235 & 103 & 40 & 15 & 65 & 18 & 78 & 522 & 135 & 42 & 184 & 147 & 99.93 \\
\hline RM 2219 & & Group 12 & 49.45 & 0.91 & 22.34 & 5.22 & 0.08 & 1.94 & 15.66 & 0.12 & 3.71 & 0.89 & 382 & 135 & 43 & 21 & 88 & 27 & 149 & 239 & 153 & 41 & 295 & 182 & 100.32 \\
\hline RM 2253 & & Group 12-2 & 29.62 & 0.62 & 17.06 & 2.58 & 0.06 & 1.21 & 46.24 & 0.01 & 1.34 & 1.26 & 158 & 101 & 23 & 18 & 55 & 17 & 49 & 372 & 112 & 39 & 142 & 156 & 100 \\
\hline RM 2271 & & Group 12 & 32.7 & 0.46 & 13.34 & 3.2 & 0.07 & 1.65 & 45.99 & 0.01 & 1.77 & 0.49 & 187 & 80 & 36 & 13 & 47 & 7 & 80 & 466 & 104 & 31 & 99 & 122 & 99.68 \\
\hline $\mathrm{M} 2$ & & 12 & & 2 & 21 & & 0 & 1 & 7 & 0 & 2.19 & 1.03 & 289 & 126 & 35 & 22 & 89 & 28 & 88 & 340 & 44 & 40 & 141 & 184 & 99.77 \\
\hline RM 3005 & & Group 12-1 & 38.59 & 0.63 & 17.48 & 4.67 & 0.13 & 1.68 & 34.13 & 0.0 & 2.1 & 0.6 & 257 & 108 & 28 & 17 & 66 & 18 & 95 & 583 & 127 & 36 & 178 & 148 & 100.02 \\
\hline M 3017 & & Group 12 & 38.58 & 0.63 & 17.39 & 4.65 & 0.1 & 1.67 & 34.26 & 0.0 & 2.08 & 0.59 & 262 & 105 & 28 & 15 & 65 & 13 & 94 & 588 & 130 & 34 & 177 & 144 & 99.99 \\
\hline RM 4081 & & Group 12-3 & 32.35 & 0.45 & 13.19 & 2.61 & 0.0 & 1.62 & 46.63 & 0.0 & 2.17 & 0.95 & 225 & 87 & 25 & 15 & 54 & 7 & 96 & 500 & 96 & 30 & 92 & 121 & 100.04 \\
\hline RM 4119 & & Group 12-1 & 34.31 & 0.54 & 15.13 & 4.09 & 0.09 & 1.71 & 41.62 & 0.01 & 2.01 & 0.82 & 205 & 95 & 31 & 17 & 57 & 14 & 83 & 581 & 111 & 32 & 94 & 134 & 100.33 \\
\hline RM 4172 & & Group 12-3 & 32.74 & 0.55 & 15.78 & 3.14 & 0.09 & 1.5 & 42.29 & 0.01 & 2.00 & 2.16 & 302 & 91 & 25 & 15 & 60 & 10 & 75 & 791 & 99 & 32 & 85 & 139 & 100.26 \\
\hline RM 4182 & & Group 11 & 35.34 & 0.5 & 14.28 & 2.95 & 0.1 & 1.69 & 42.28 & 0.01 & 2.29 & 0.47 & 203 & 93 & 41 & 14 & 56 & 13 & 102 & 666 & 97 & 28 & 91 & 124 & 99.91 \\
\hline RM 3060 & & Group 19 & 25.61 & 0.3 & 7.2 & 1.98 & 0.03 & 1.44 & 61.97 & 0.01 & 1.02 & 0.37 & 113 & 59 & 29 & 9 & 33 & 12 & 45 & 357 & 75 & 25 & 442 & 127 & 99.93 \\
\hline RM 3068 & & Group 19 & 30.58 & 0.3 & 8.8 & 2.02 & 0.0 & 1.26 & & $0 .($ & 1.26 & 0.36 & 133 & 80 & 10 & 12 & 51 & 10 & 58 & 317 & 74 & 26 & 96 & 147 & 99.87 \\
\hline RM 3069bi & & oup 19 & 20.69 & 0.2 & 5.98 & & 0.03 & 1.36 & 68.43 & 0. & 0.75 & 0.62 & 99 & 55 & 32 & 11 & 33 & 12 & 34 & 398 & 58 & 20 & 195 & 113 & 99.65 \\
\hline RM 3115 & & 19 & 33.18 & 0.4 & 9.23 & 2.47 & 0.0 & 1.55 & 51.68 & 0. & 1.19 & 0.27 & 131 & 73 & 18 & 13 & 32 & 12 & 66 & 296 & 94 & 25 & 167 & 151 & 100.03 \\
\hline RM 3 & & up 19 & 31.76 & 0.3 & 7.28 & 18 & 0.03 & 1.35 & 57.52 & 0. & 1.1 & 0.16 & 58 & 58 & 38 & 10 & 27 & 12 & 55 & 334 & 68 & 18 & 103 & 136 & 101.47 \\
\hline RM 3061 & & Group 19 & 24.77 & 0.31 & 7.06 & 1.63 & 0.03 & 2.29 & 64.14 & 0.11 & 0.93 & 0.29 & 58 & 53 & 19 & 9 & 30 & 13 & 48 & 335 & 61 & 18 & 71 & 102 & 101.56 \\
\hline RM 3077 & & Group 19 & 22.53 & 0.24 & 5.26 & 1.56 & 0.03 & 1.31 & 69.45 & 0.12 & 0.83 & 0.36 & 21 & 43 & 13 & 9 & 26 & 10 & 35 & 343 & 49 & 18 & 82 & 110 & 101.69 \\
\hline RM 3080 & & Group 19 & 21.61 & 0.25 & 5.42 & 1.3 & 0.04 & 1.39 & 70.5 & 0.06 & 0.65 & 0.38 & 21 & 40 & 10 & 8 & 24 & 10 & 31 & 403 & 42 & 17 & 86 & 105 & 101.6 \\
\hline
\end{tabular}




\section{Petrographic and palaeontological analyses}

The sediments and fired pottery pastes were observed under binocular and optical microscopes, using polarized light (Fig. 7). Binocular observation was used for the identification of large fossil inclusions. The determination of the oyster species allows the geological age of the sediments to be dated. The provenance of the raw materials was determined by comparison of archaeological ceramic samples with sediments from natural outcrops, following the method proposed by Tite (1999). About $1 \mathrm{~kg}$ of each sediment type, from 30 to $50 \mathrm{~cm}$ below the surface, was sampled.

\section{Chemical analyses $(X R F)$}

Ten major elements and 12 trace elements have been chemically analysed by XRF (Philips PW 2400). Oxides are in weight percent and trace elements in ppm. The error margin is $1 \%$ for major elements and $10 \%$ for trace elements.

$\mathrm{FeO}$ wt\% was measured with dipyridil protocol, using the Philips Pye Unicam PU 8650 spectrophotometer.

\section{Calcimetry}

The percentage of $\mathrm{CaCO}_{3}$ is deduced from the measure of $\mathrm{CO}_{2}$ volume produced by destruction of sediment with $\mathrm{HCl}$ solution (30\%). Quantities measured for the samples are related to a reference obtained on pure $\mathrm{CaCO}_{3}$.

\section{Grain-size analyses}

Grain-size analyses of the matrix are rarely performed on archaeological clayey artefacts, because the technique is only valid before clay firing (Fig. 7). It is important to not confuse grain-size analysis of inclusions (natural or added) and grain-size analysis of matrix (clay, silt or sand, in the granulometric sense). This second type of analysis, here using the laser method, is rarely performed in archaeometry because of clay firing. Some textural or grain-size analyses have been performed in ethno-archaeological contexts (Gosselain 1994; Livingstone Smith 2000; Mercader et al. 2000).

Grain-size analyses (from $0.5 \mu \mathrm{m}$ to $2 \mathrm{~mm}$ ) were performed after extraction of the $>2 \mu \mathrm{m}$ fraction, using a Laser Sizer Coulter LS32, after sieving at $2 \mathrm{~mm}$. A few milligrams of each sample were placed in the LS32 vat, and dispersed by ultrasonic waves. During analysis, the laser ray is diffracted by particles and focused in a detector. An overestimate of the grain size of particles smaller than $2 \mu \mathrm{m}$ may occur. Therefore, results obtained on the clay fraction $(<2 \mu \mathrm{m})$ cannot be considered as absolute values, but only as a way of comparing the different sediments studied.

In order to obtain detailed information on grain-size distribution, grain-size data were treated according to the method described by Wang et al. (1999), Lacroix et al. (2000) and Lesourd (2000). We considered the grain-size frequency spectra for the volume for a range of particle sizes from $0.5 \mu \mathrm{m}$ to $2 \mathrm{~mm}$. The populations of particles can be distributed over a number of lognormal curves, which allows the determination of each individual constituent. 
Therefore, grain-size frequency spectra are sums of grain-size populations distinguished by their mode, and were characterized by the relative area of these populations, related to the bulk area of the grain-size distribution curve, and then compared one to another. A smoothed second derivative method was used in order to distinguish the grain-size populations and determine their mode.

\section{$X$-ray diffraction}

Bulk sediment and clay fractions were analysed by XRD. For the bulk sediment analyses, each powdered sample was analysed using a Philips PW 1710 diffractometer running between $3^{\circ}$ and $65^{\circ} 2 \theta$ at $40 \mathrm{kV}$ and $20 \mathrm{~mA}$, using $\mathrm{Cu}-\mathrm{K}_{\alpha}$ radiation, a Ni filter and a scan speed of $1^{\circ} \mathrm{min}^{-1}$. In preparation for the XRD of the clay fractions, the samples were dispersed on de-ionized water, disintegrated, decarbonated with $\mathrm{HCl}(0.2 \mathrm{M})$ solution and washed several times before separation of the $<2 \mu \mathrm{m}$ fraction by settling in a water column. A preparation of oriented aggregates of clays was then collected on a glass slide. The samples were sequentially air-dried, glycolated and heated for $4 \mathrm{~h}$ at $490^{\circ} \mathrm{C}$ for identification of the clays; that is, the (001) basal reflections. Two samples were treated with hydrazine in order to identify the presence of kaolinite. The analyses were performed using the same conditions as for the bulk samples, but between $2^{\circ}$ and $32^{\circ} 2 \theta$.

\section{The Rietveld method}

Rietveld refinements of the powder X-ray patterns allow quantitative information to be obtained about the mineralogical composition of the samples (Bish and Post 1993). The method consists of comparing the measured pattern with a calculated pattern that is based on a model provided by the user. The input model parameters-for example, the phases present, the proportion of each phase, the structure data, the instrumental parameters, the peak profile parameters and so on-are given approximate starting values that are varied in a least-squares procedure until the calculated pattern best matches the observed pattern. The SIROQUANT program (Taylor 1991) was used for the least-squares refinements. Zero shift, sample displacement and peak shape, modelled with a Pearson VII profile function, were the instrumental parameters, which were refined. The structure information for the present phases was taken from the SIROQUANT data bank, but only the unit cell parameters were refined. The atomic positions and the site occupancy were kept fixed during the refinement. This is acceptable, considering the usually small deviation from endmember stoichiometry observed for most of the present phases (quartz, calcite). The composition of the ankerite phase was estimated using the dependency of the lattice parameter on the iron content. The refined lattice parameters $(a=4.830$ $\AA$ and $c=16.167 \AA$ ) are compatible with the following stoichiometry: $\mathrm{CaMg} 0.5 \mathrm{Fe} 0.5\left(\mathrm{CO}_{3}\right)_{2}$. The phyllosilicate with $10 \AA$ layer spacing was modelled with an illite structure. The analysis of the clay fractions separated from the bulk sediment shows that the situation is more complex in the presence of smectite and mixed-layer illite-smectites. The peaks associated with these phases, however, do not show up in the diffractogram of the bulk material, indicating that they are present only in minor concentrations. 